\title{
Qualitative analysis of elderly physical activities development strategies and policies of selected and leading countries
}

\section{Aboulfazl Goodarzi}

PhD Student in Sports Management. Kharazmi University and the faculty of Payame Noor University. Tehran. Iran.

\section{Alireza Elahi}

* Sports Management Group. Faculty of Physical Education and Sports Sciences, Kharazmi University. Tehran. Iran. (Corresponding Author) alirezaelahi@ yahoo.com

\section{Hosein Akbari Yazdi}

Sports Management Group. Faculty of Physical Education and Sports Sciences, Kharazmi University. Tehran. Iran.

\section{Received: 2020/09/29}

Accepted: 2020/11/17

Doi: 10.29252/ijhehp.8.4.1

\section{ABSTRACT}

Background and Objective: Iran will become the oldest country in the foreseeable future according to Iran's statistical center report. Improvement of physical activity level between elderly is one of the most effective factors in correcting people's life style and helps in successful aging. Using the leading countries experience as appropriate pattern could consider as one of the backgrounds of macro planning for elderly physical activity developments. We tried in this survey to extract and conceptualize valuable points that are useful in area of aging crisis management for country's health and sports department future planning.

Materials and Methods: 23 valid and strategic documents and documents of elderly physical activity development planning of successful countries and valid and relevant international organization analyzed Which were uploaded and published in a reputable database between 2001 and 2019; They were crawled by Google Scholar and Google search engines and were validated in reputable databases such as ISI and Scopus or uploaded to government and official websites. Using the qualitative method of content analysis and the network of themes by the method of Brown and Clark (2006) until the theoretical saturation was analyzed. Manually and researcher-centered the Key, organized and basic themes conceptualized during 4 coherent phases of analysis and search for themes for this purpose and finally, their thematic network was drawn.

Results: The results of data codification during three phases and summarization of extracted key themes caused detection of 32 coherent themes and 5 basis themes including basic and structural components, software components, hardware components, social and cultural components and operational components, in addition to thematic network.

Conclusion: It is recommended that, country's health and sports department managers and authorities codify and perform useful strategic and operational plans for encountering to aging crisis and citizen successful aging by using this collection of extracted themes.

Keywords: elderly sports, strategic planning, successful aging, physical activity, themes analysis.

Paper Type: Research Article.

Citation (Vancouver): Goodarzi A, Elahi A, Akbari Yazdi H. Qualitative analysis of elderly physical activities development strategies and policies of selected and leading countries. Iran J Health Educ Health Promot. Winter 2021;8(4): 359-377. [Persian]x

- Citation (APA): Goodarzi A., Elahi A., Akbari Yazdi H. Qualitative analysis of elderly physical activities development strategies and policies of selected and leading countries. Iranian Journal of Health Education \& Health Promotion., 8(4), 359-377. [Persian] 


\section{تحليل كيفى سياستها و راهبردهاى توسعه فعاليتجسماذى سالمندان كشورهاى ييشرو منتخب}

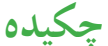

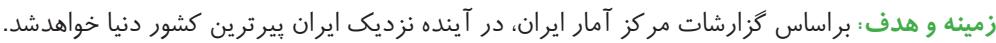

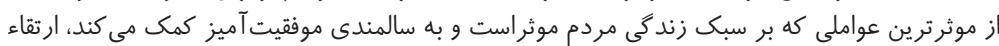

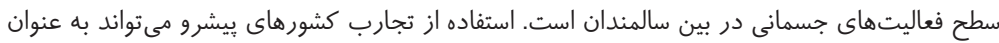

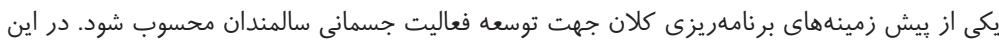

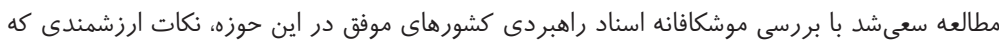

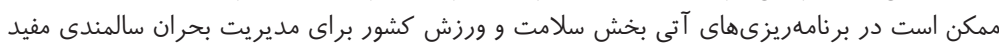

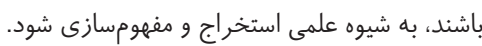

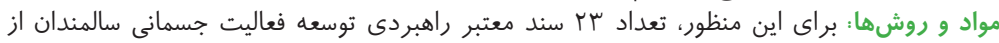

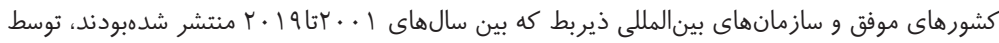

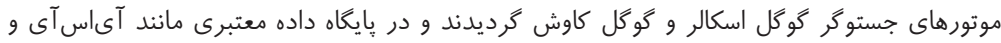

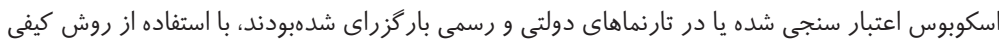

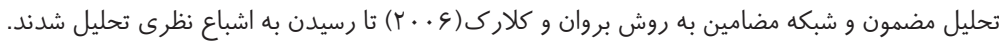

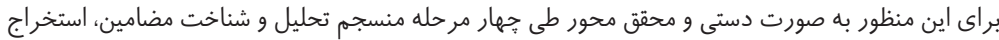

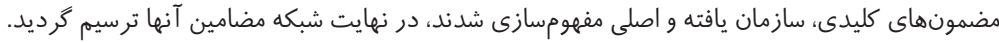

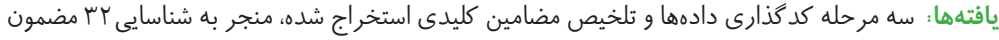

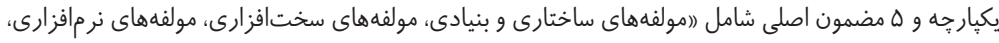

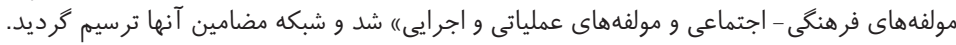

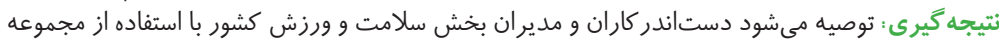

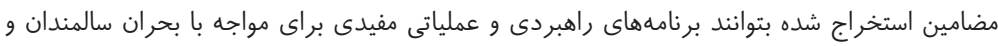

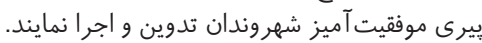

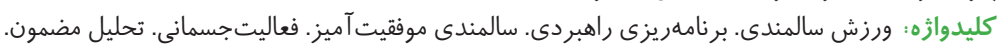
نوع مقاله : مطالعه يُزوهشى.

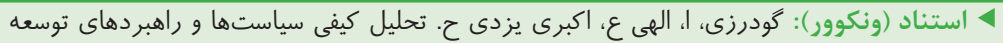

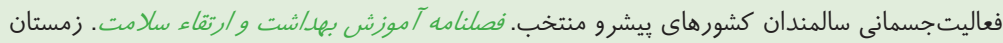
$r \vee r \vee-r \Delta q:(\mathcal{F}) \wedge: 1 \% q 9$

4 استناد (APA): گودرزى، ابوالفضل؛ الهى، عليرضا؛ اكبرى يزدى، حسين. (زمستان 99 (1)). تحليل

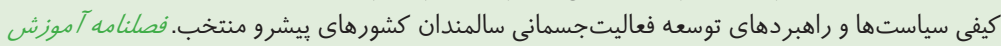

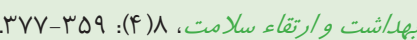

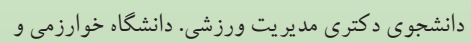
هيات علمى دانشكاه بيام نور. تهر ان. ايران

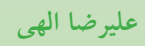

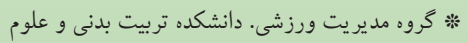
ورزشى دانشكا. خوارزمى. تهران. ايران. (نويسنده alirezaelahi@yahoo.com

مسئول)

$$
\text { حسين اكبرى يزدى }
$$

كروه مديريت ورزشى. دانشكده تربيت بدنى و ورى علوم ورزشى دانشكاء خوارزمى. تهران. ايران

تاريخ د ريافت:

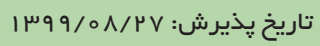


اشاره مى گردد، ا.ساختن يك بستر مناسب براى نو آورى و تغيير.

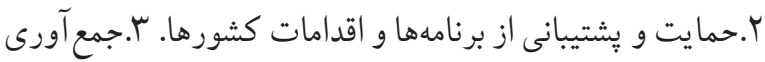

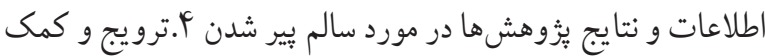

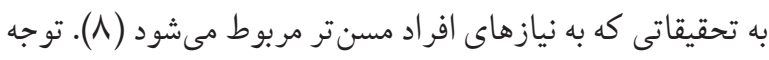

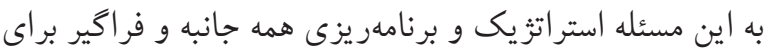

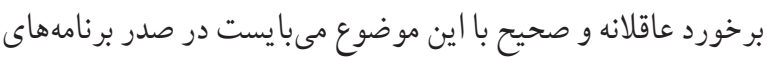
مديران ارشد كشور جهت حمايت منطقى و علمى از سالمندان باشد. يكى از موثرتر ين موضوعاتى كه مىتواند تاثير بسزايى بر اصلاح

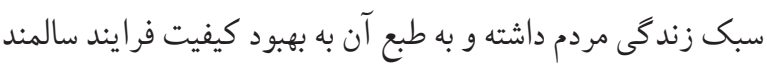

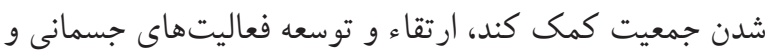

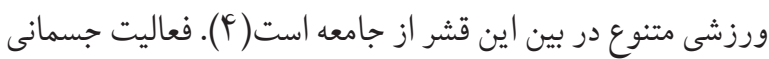

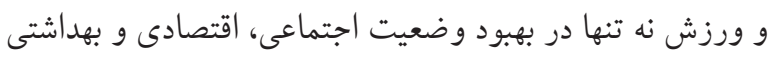

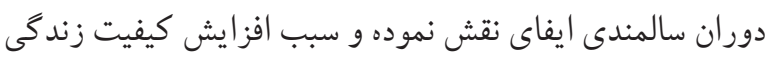

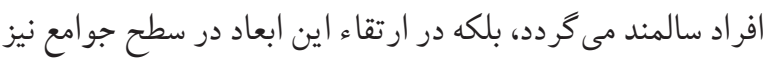
موثر به نظر مىرسد ( • (و 9). جهت رسيدن به اهداف مطلوب در توسعه و ترويج فعاليت

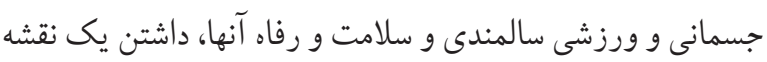

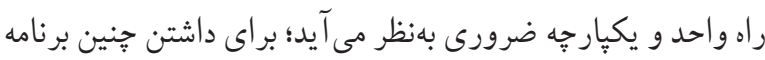
استراتزيك و همه جانبهاى لازم است با مراجعه به تجربيات ساير بـ بهري

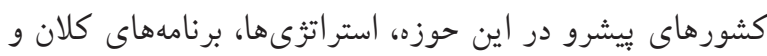

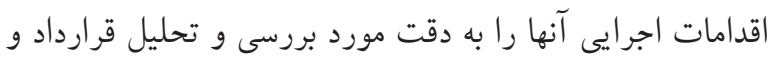

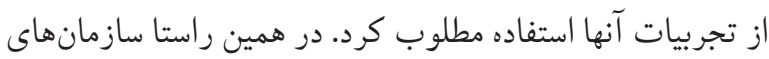
بين المللى ذيربط و يزولهشكران و صاحبنظر ان مختلف بر اهميت

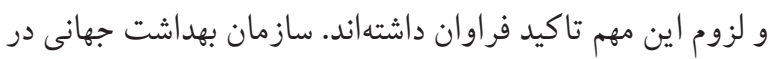
دستو رالعمل هاى متعدد بر تبادل اطلاعات بين كشورهاى عضو تاكيد

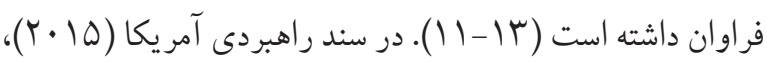

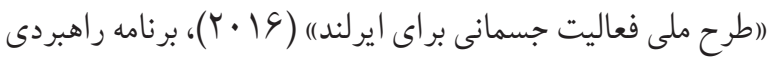

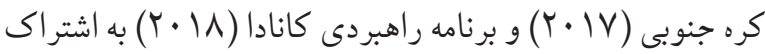
كذاشتن برنامها، تجربيات و تلاشهاى موفق در زمينه ارتقاء مشاركت

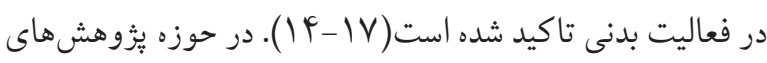

طبق آمارهاى اعلام شده از سوى مركز آمار كشور در سال ITVD

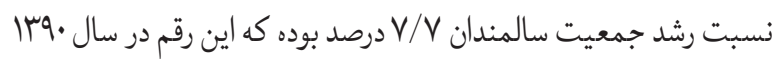

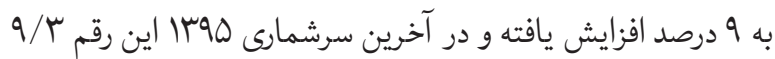
درصد اعلام گرديد (1). بر اساس گزارش شاخص جهانى ديدهبان

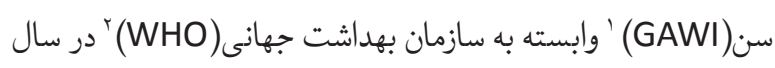

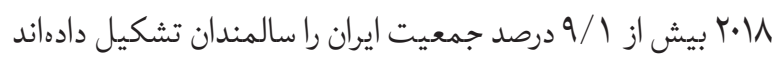

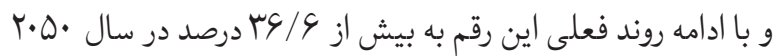

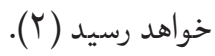

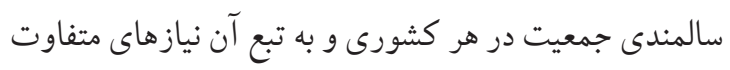
اين قشر، از مهمترين مسائل ييشروى نظامهاى سلامت در آينده

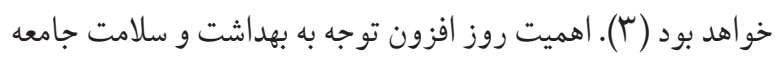

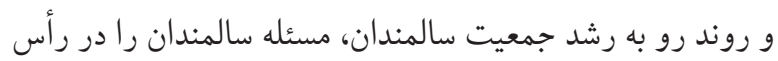
موضوعات مرتبط با جامعه قرار داده است. از سوى ديخر موضوع

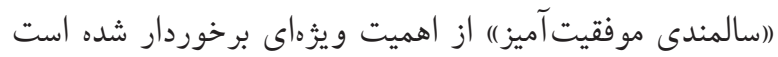

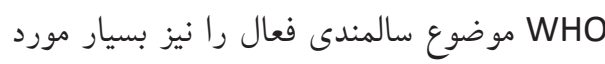
تاكيد فراوان قرارداده است(ه). سالمندى فعال در سطح كلانتر به عنوان زيربناى استر اتزى هاى سياستى حوزه سالمندى در سازمان

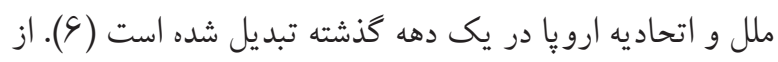

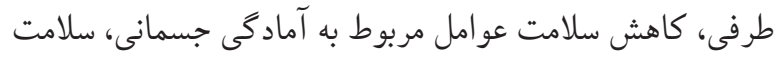
روانى و كيفيت زندكى ناشى از كم تحركى، يك تهديد براى سلامت سالمندان است كه موجب تغيير كيفيت زندگى و بالا رفتن

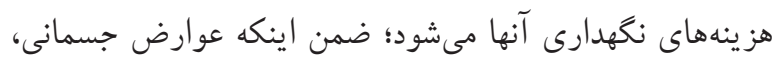

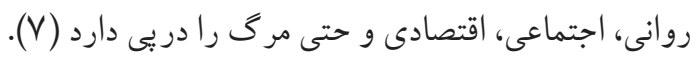

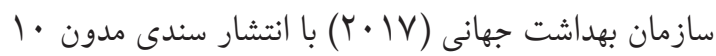
اولويت يك دهه اقدام موثر براى ييرى سالم را تعيين و به همه

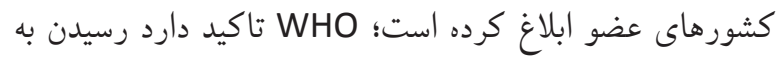
جشم انداز سالمندى سالم، بدون يك فعاليت متمركز و مستمر جهانى، ميسر نخواهد شد. در ادامه به برخى استراتثىهاى اين سازمان بدان

1. Global Age Watch Index

2. World Health Organization (WHO) 
هر برنامه راهبردى در اين خصوص، آشنايى با تجربيات كشورهاى ويشرو و استفاده صحيح از دانش و تجربه هاى مفيد آنهاست. نتايج

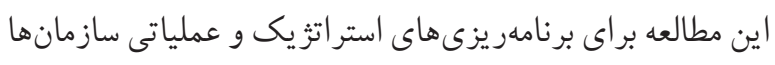

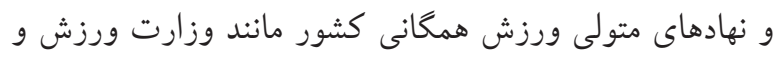

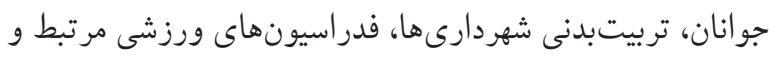

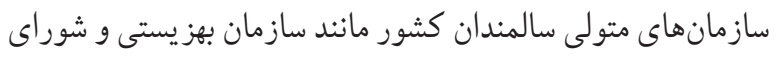
ملى سالمندان كشور و مانند آن، مفيد و كاربردى خواهد بود. اين

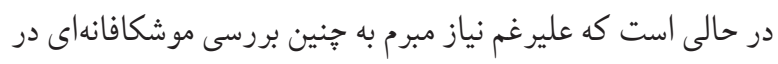
خصوص عملكرد و برنامههاى كشورهاى موفق در توسعه فعاليت

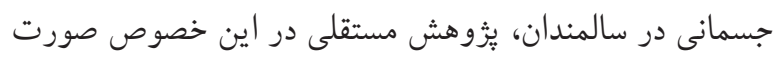

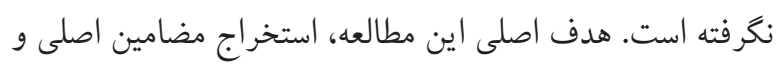

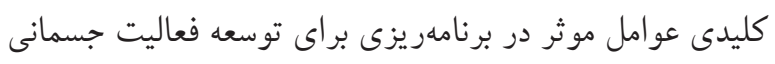

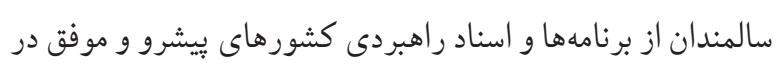

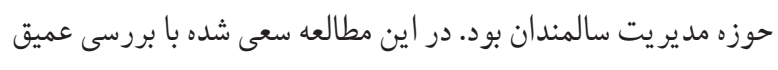

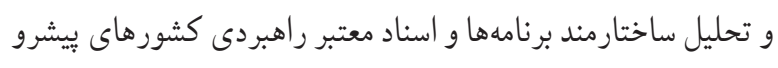

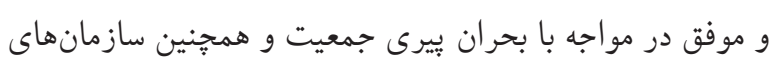

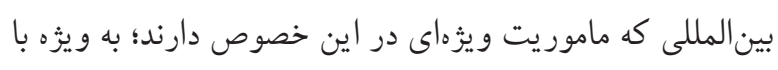

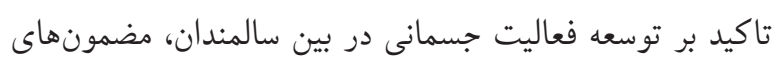

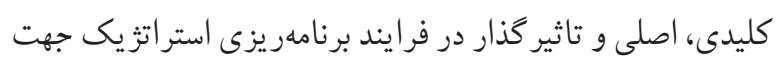
توسعه و ترويج فعاليت بدنى در سالمندان را استخراج و به شيوه علمى كزارش نمايد. روش كار از آنجايى كه اين مطالعه در بيى شناسايى و استخراج عوامل ناشناخته

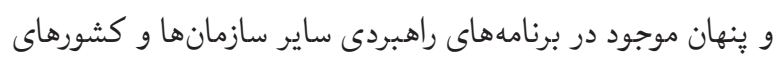
بيشرو در حوزه فعاليت جسمانى سالمندان جهت توسعه و ترويج

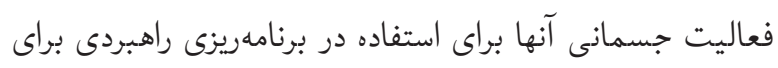

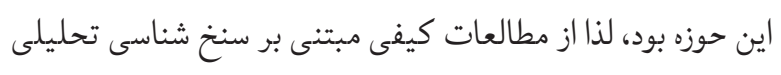

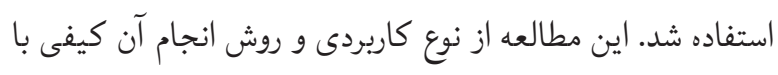
استفاده از تكنيك تحليل مضمون' و شبكه مضامين ب بود. تحليل مضمون، روشى براى شناخت، تحليل و كزارش الكوهاى موجود در

1. Thematic analysis method

2. Thematic network
صورت گرفته در داخل نيز يزوهشخران مختلف بر لزوم توجه و

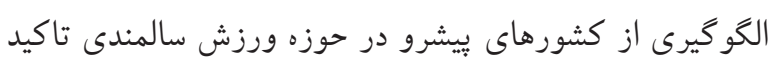

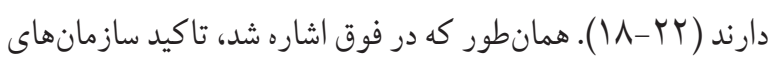
بين المللى و متولى در حوزه سلامت و بهداشت جهانى و برنامههاى

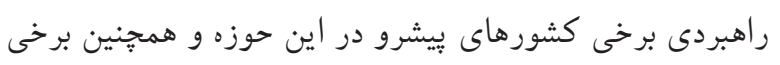

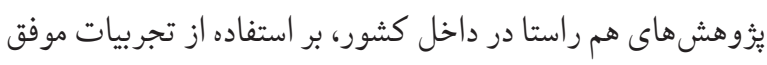

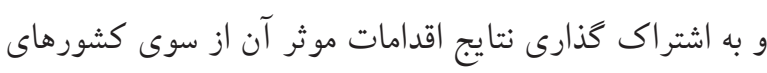

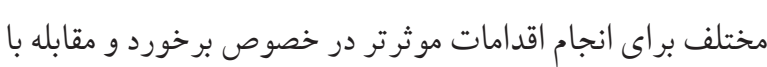

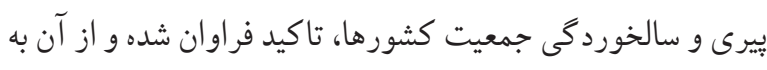

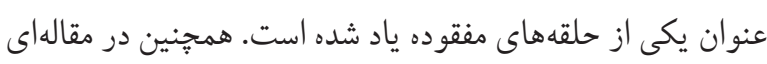

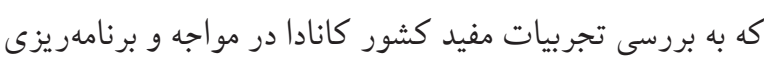

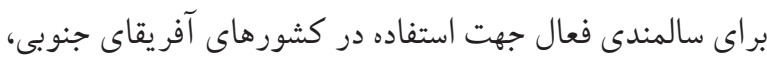
ير داخته بود؛ ينج راهكار عمومى به عنوان توصيه بيشنهاد مى كند؛ إ.

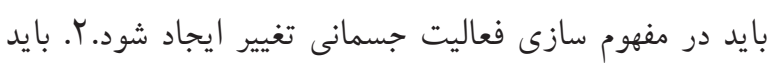

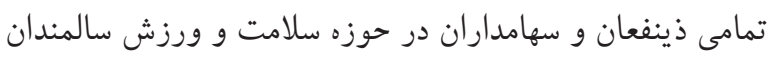

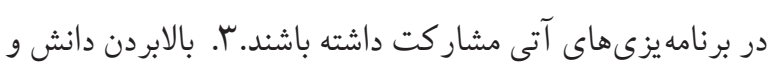

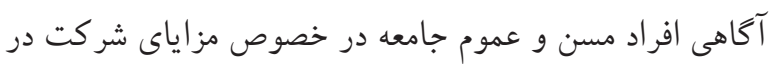

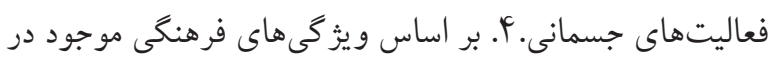

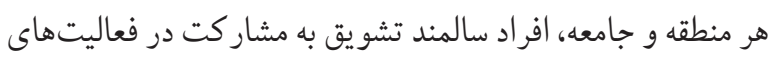

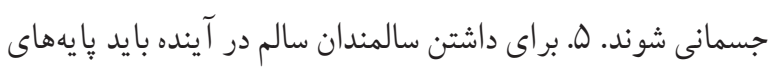

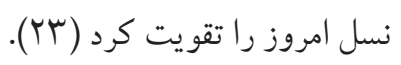
براى كنترل هو شمندانه و فائق آمدن بر مسئله بسيار مهم سالمند

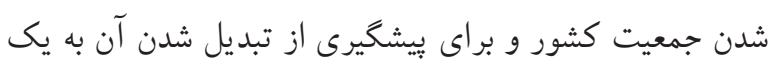

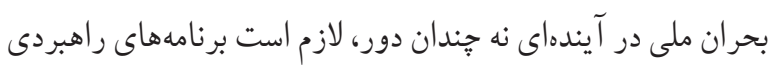

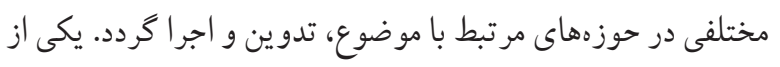

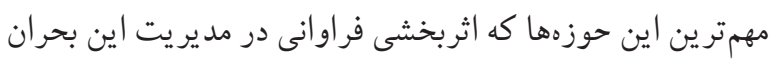

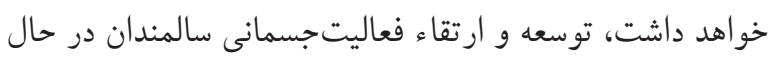

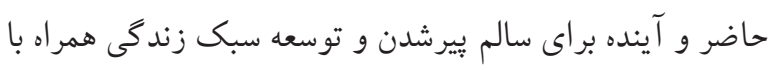
فعاليت جسمانى در سالمندان است. اين مهم مى تو اند ساير زمينهها

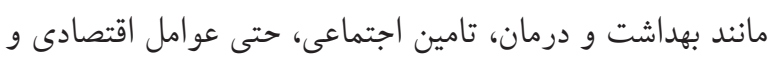
اجتماعى را تحت تاثير عميق خود قرار دهد. اولين قدم براى تدوين 
اين حوزه قلمداد شوند، اين مهم در سايت سازمان بهداشت جهانى، بخش بهداشت سالمندان كشورهايى كه داراى برنامه راهبردى مورد

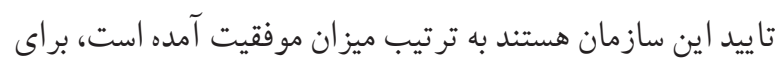

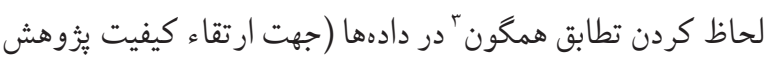

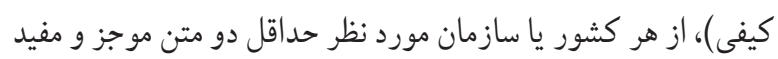

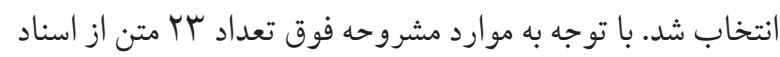

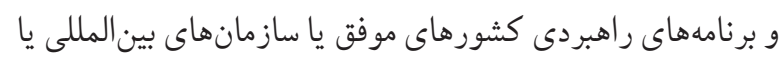

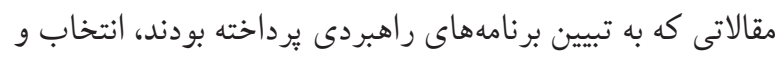

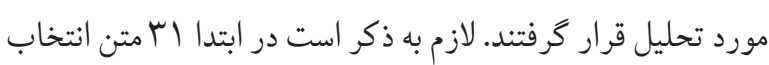

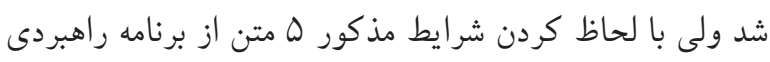

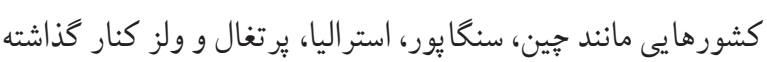

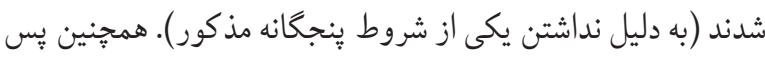

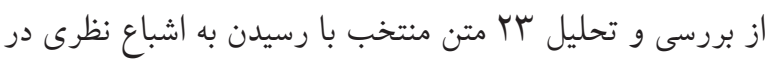

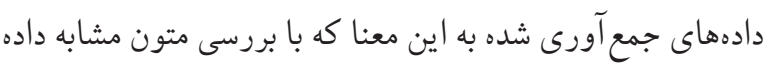

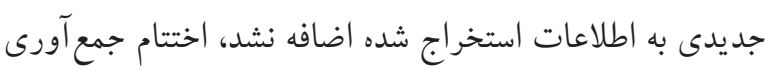

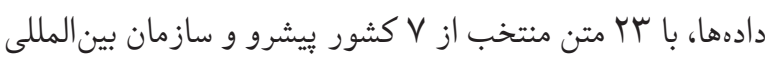

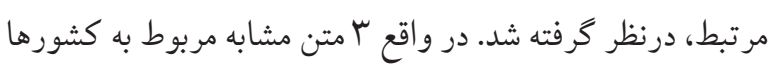
و سازمانهاى بين المللى هفتخانه بود كه در مطالعه وارد نشدند.

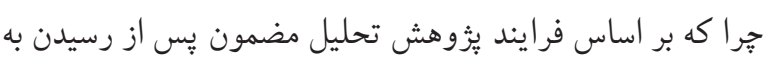

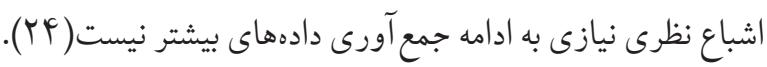

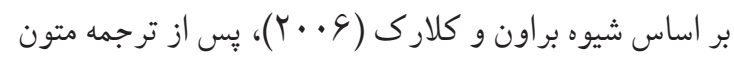

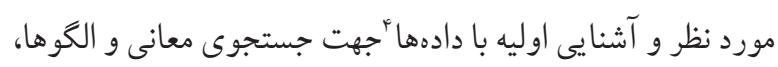

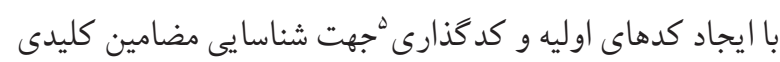

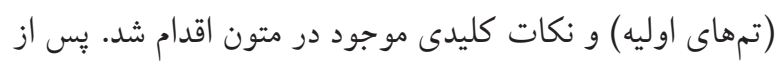
جندين مرتبه مطالعه عميق متنها و استخر اج تمامى مضامين كليدى،

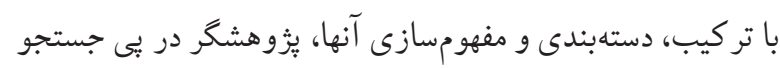

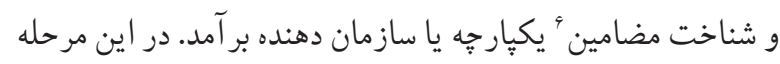

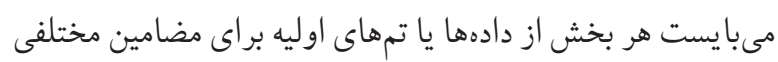

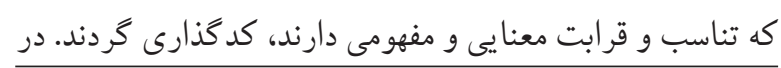

3. Traingulation

4. Familiarization with the datas

5. Generate initial codes

6. Search for team
دادههاى كيفى است. اين روش فرايندى براى تحليل دادههاى متنى

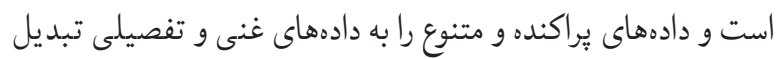
مى كند. تحليل مضمون، تحليلى مبتنى بر استقراى تحليلى است.

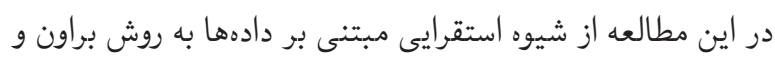

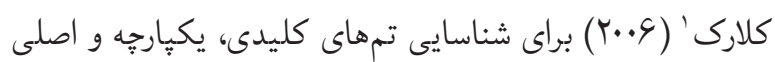

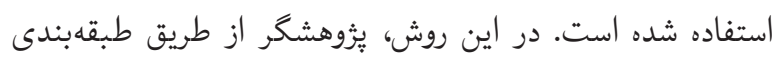
دادها و الكويابى درون و برون دادهاى به يك سنخ شناسى تحليلى ئى

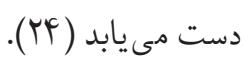
براى شناسايى و انتخاب متون مورد نظر جهت بررسى و تحليل،

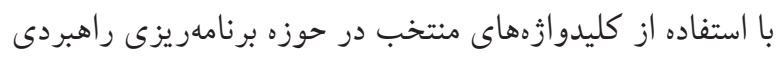
در توسعه و ترويج فعاليت جسمانى سالمندان (سالمند، يبرى،

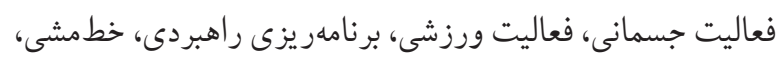

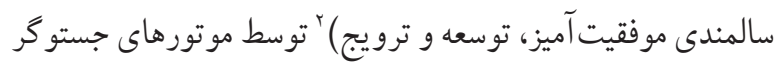

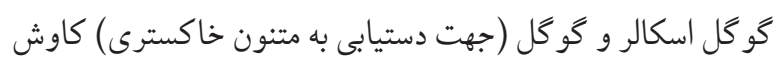

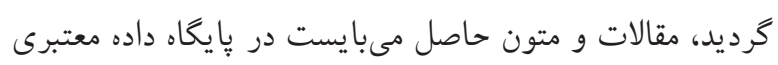
مانند تارنماى بهداشت و درمان، ورزش، سازمان متولى سالمندان

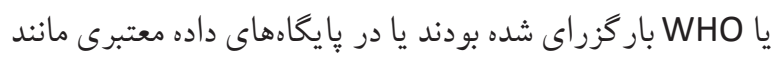

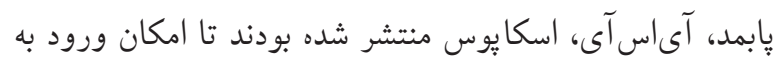

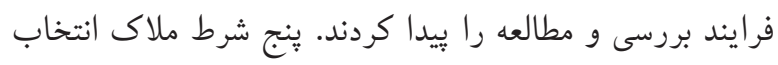

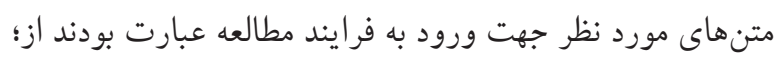

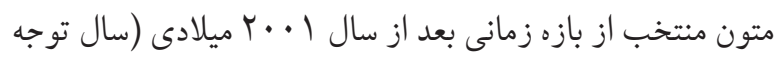
و تاكيد سازمان بهداشت جهانى به مقوله سالمندى جمعيت جهان)

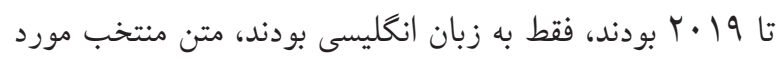
تاييد سازمانى معتبر و تخصصى در حوزه سالمندان (مانند سازمان بهداشت جهانى يا سازمانى مرتبط در كشور مورد نظر مانند وزارت

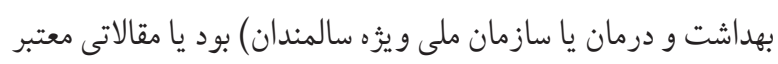
كه با موضوعيت توسعه فعاليت جسمانى در سالمندان تدوين شده

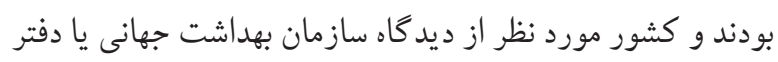

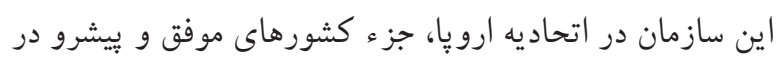
successful aging, development and promotion. 
مديريت بحران سالمندانى و توسعه ورزش همگانى كه از دانش و

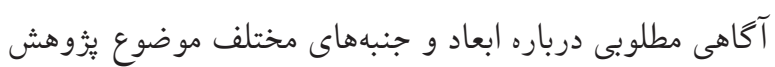
برخوردار بودند، مورد اصلاح و تاييد قرار گرفت (Y (Y

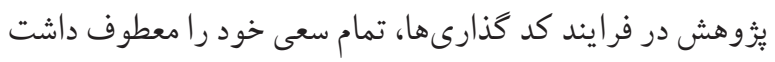

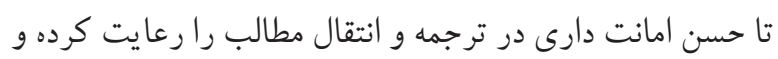

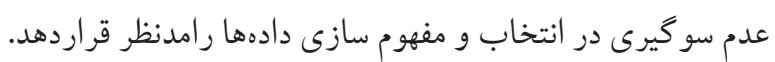

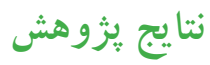

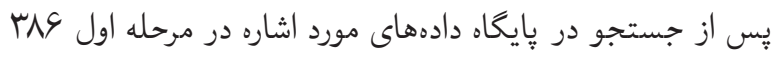

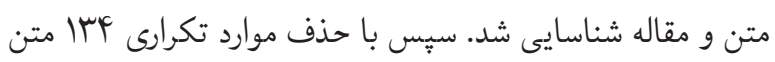
غربال گرديد. در مرحله بعد با لحاظ كردن شروط ينجگانه مشروح در بخش روششناسى ابتدا تعداد الم متن برنامه راهبردى و مقاله

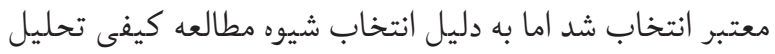
مضمون و لزوم وجود حداقل دو متن معتبر در فرايند مطالعه جهت افزايش پِيايى نتايج، ه متن از مطالعه خارج گرديد. در فرايند

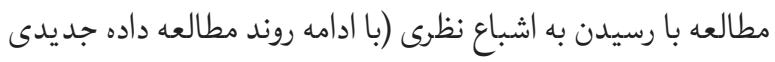
به اطلاعات تحقيق اضافه نمى گردد) بم متن از بررسى و تحليل

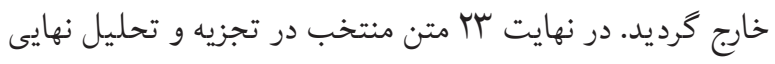
مورد بررسى و مطالعه قرار گرفت.

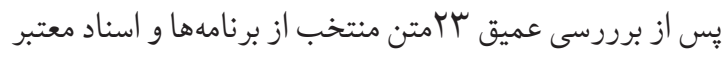

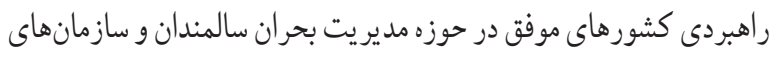

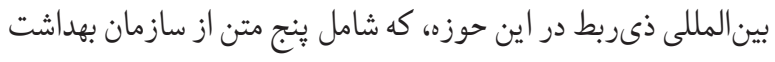

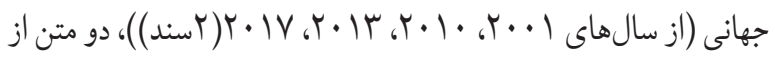

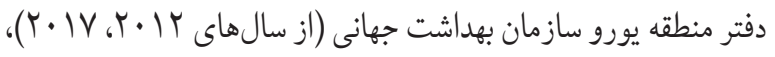

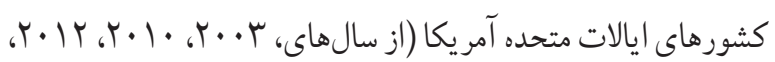

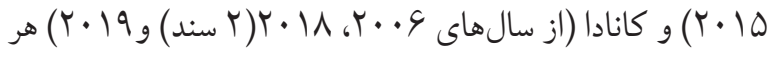

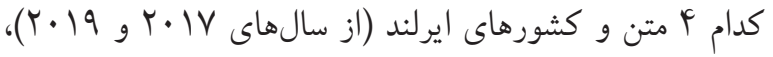

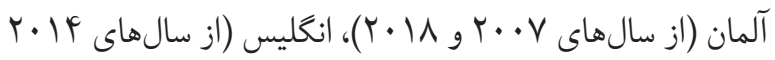

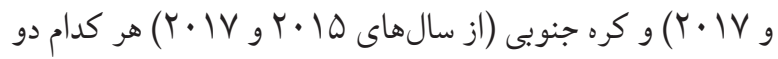
متن موجز و معتبر بودند و شرايط يُنجانه تشريح شده در قسمت

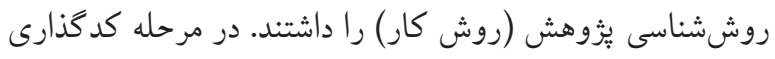

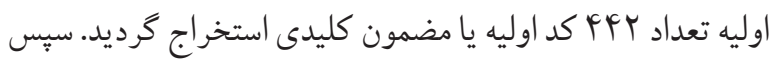

مر حله جهارم كد گذارى، مضمونهاى يكِارجه (تم فرعى) استخراج شده يك بار ديكر با تلخيص مضامين دستهبندى مفهومى و معنايى شده و در يك مفهوم كلى تر و كلانتر به عنوان مضامين اصلى يا كلان مفهو مسازى شدند؛ در نهايت با داشتن تصو ير كلى از مفاهيم

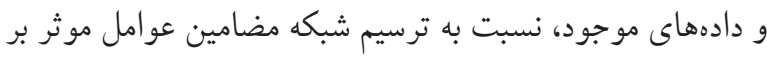
تدوين برنامه راهبردى توسعه و ترويج فعاليت جسمانى سالمندان

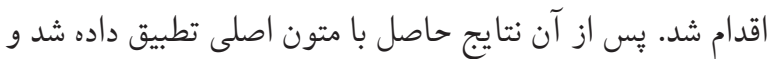

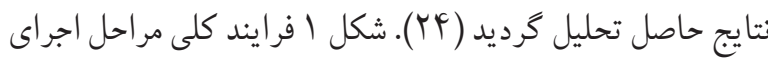
يُزوهش تحليل مضمون رابه تصوير كشيده است.

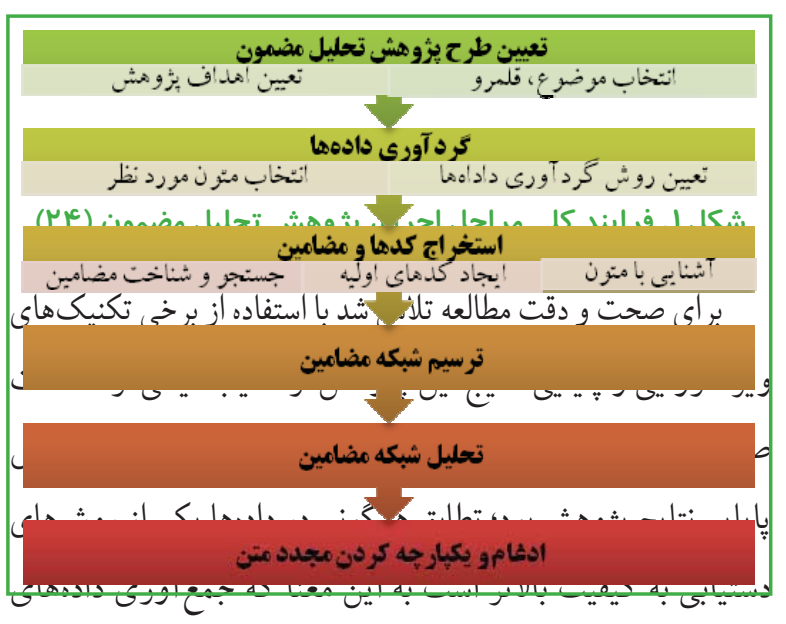
مختلف از منابع مختلف، جهت مطالعه يديدهاى واحد صورت مى گيرد. در اين مطالعه با انتخاب حداقل دو متن موجز و معتبر از هر كشور

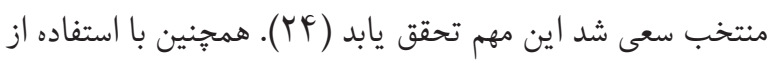

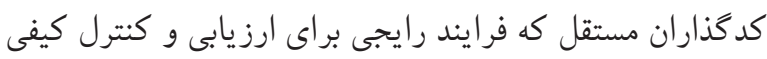
تحليل مضمون است، جهت بررسى مجدد مضامين كليدى، مضامين

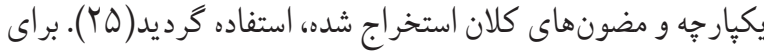
اين منظور از جهار نفر از متخصصان درون و بيرون از تيم يُزوهش

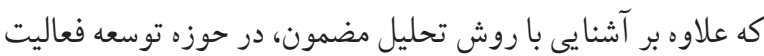

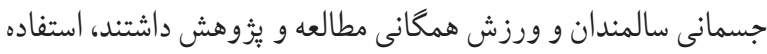

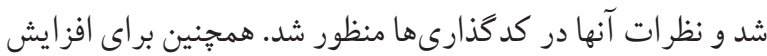
روايى نتايج يُووهش، نتايج نهايى كد گذارىها و شبكه مضامين

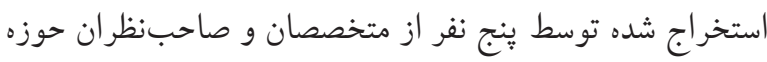


به عوامل اصلى و بنيادى مانند ساختار سازمانى ملى، سند ملى و حمايتهاى قانونى و ايجاد شبكههاى همكارى بين بخشى و درون بخشى در بخش كلان كشورها همجٍنين فرايندهاى نظارت و ارزيابى و دركيركردن همه ذينفعان موثر در موفقيت برنامههاى راهبردى و عملياتى جهت برنامهريزى راهبردى در خصوص توسعه فعاليت جسمانى سالمندان اشاره دارد. در جدول شمارها مضامين استخراج شده از متون منتخب و دسته بندى و مفهوم سازى آنها براى مولفههاى ساختارى و بنيادى به همراه مصاديقى از متنون منتخب به تفصيل آمده است. مولفههاى سخت افزارى؛ مولفههاى سخت افزارى توسعه زيرساخت هاى شهرى و روستايى وافزايش فرصت ها شامل توسعه و ارتقاء زيرساختها و اماكن و امكانات مانند فضاهاى روباز و سريوشيده وززشى و مسيرهاى دوجرخه سوارى و پيادهراهها و رفع موانع فيزيكى، اجتماعى و فرهنكى برداختن به فعاليت جسمانى، همجنين عوامل اقتصادى توسعه زيرساخت هاى اقتصادى و حمايتهاى مالى دولت و تربيت نيروهاى انسانى مجرب و متخصص را در بر مى گيرد؛ در جدول
در مرحله بعد با دستهبندى و مفهوم سازى مضامين كليدى كه قرابت مفهوم و معنايى داشتند، تعداد ب مضمون يكيارجه يا سازمان دهنده،

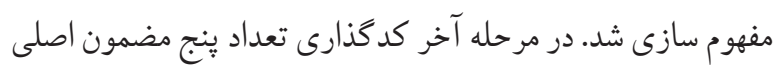
يا كلان جمعبندى گرديد. در نهايت با داشتن تصوير كلى از مفاهيم و دادهاى موجود، شبكه مضامين عوامل موثر بر تدوين برنامه راهبردى توسعه و ترويج فعاليت جسمانى سالمندان ترسيم شد. جداول شماره يك الى ينج مضامين اصلى (تم اصلى)، مضامين يكيارجه -كه حاصل تر كيب و مفهوم سازى شدهضونهاى كليدى از متون اصلى منتخب مورد بررسى - و جِكيدهاى از مضامين كليدى بر گرفته از متون رابه تفصيل نشان مى دهند. همانطور كه جداول نيز نشان مىدهند بهطور كلى ينج تم اصلى (مضمون كلان) را مى توان براى مفهوم اصلى توسعه و ترويج فعاليت جسمانى سالمندان مد نظر قرارداد. اين مضامين كلان يا تمهاى اصلى شامل ((مولفههاى ساختارى و بنيادى، مولفههاى سختافزارى، مولفههاى نرمافزارى، مولفه هاى فرهنكى - اجتماعى و مولفه هاى عملياتى و اجر ايى)" بودند. مولفهاى ساختارى و بنيادى، مولفهاى ساختارى و بنيادى

جدول ا. مضامين استخراج شده از متون منتخب براى مفهوم سازى مولفه هاى ساختارى و بنيادى

مصاديقى از متون

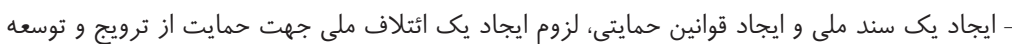

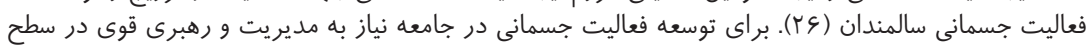

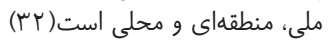

\section{تمهاى فرعى}

-

قانونى

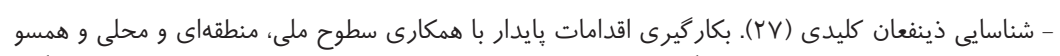

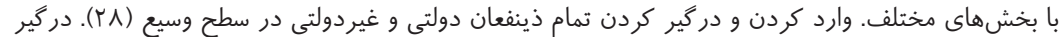

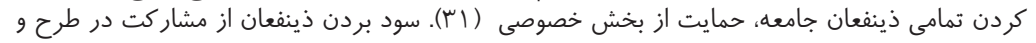
- ساختار سازمانى -

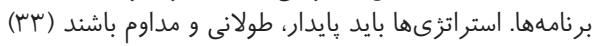

\begin{tabular}{|c|c|}
\hline 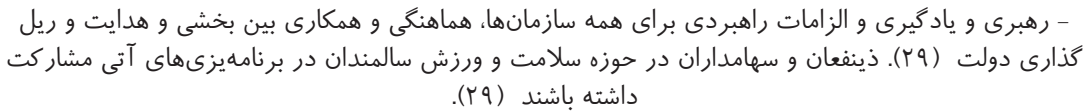 & - رهبرى يكيار خه و \\
\hline
\end{tabular}

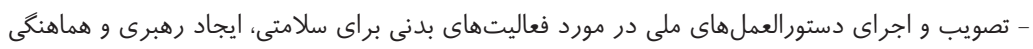

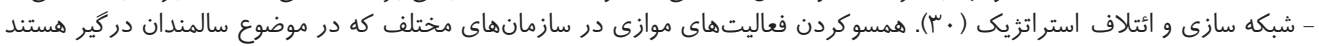

(ry)

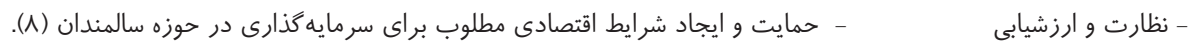

- خصوصى سازى - مكانيسم هماهنگى دولت ملى و رهبرى ترويج فعاليت جسمانى، حمايت از سازمانها و دولتهاى محلى ( (1).

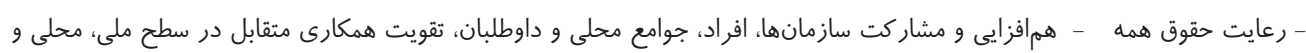

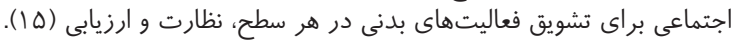

ذينفعان 
و يُزوهشهاى كاربردى و اثربخش و كاربردى كردن نتايج آنها،

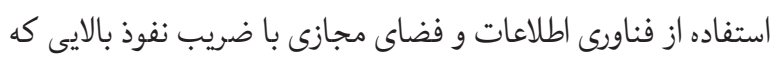

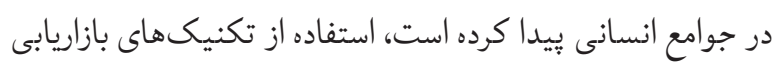

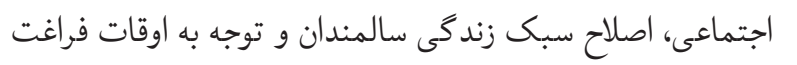
و تفريحات آنها و نكته بسيار مهم توسعه مشاركت مدنى سالمندان

جدول r. مضامين استخراج شده از متون منتخب براى مفهوم سازى مولفهاى سخت افزارى

تم اصلى N تمهاى فرعى م مصاديقى از متون

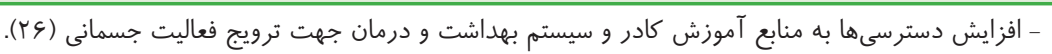

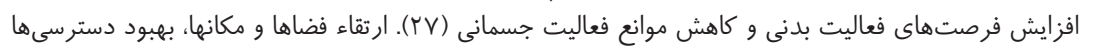

(ץ)

- كاهش نابر ابرىهاى دسترسى به فرصتهاى فعاليت بدنى. تبديل انتخاب فعال بودن به يك انتخاب

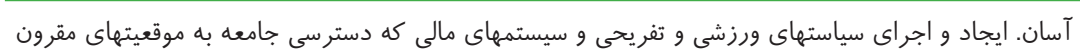

-

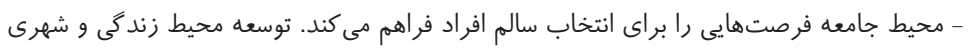

جامعه براى برداختن به فعاليت جسمانى و ورزشى. در دسترس قراردادن برداختن به فعاليت جسمانى براى

همه سالمندان (هَ).

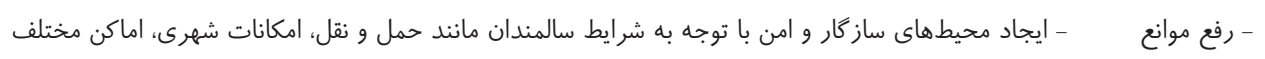

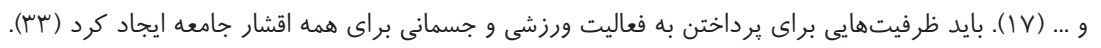

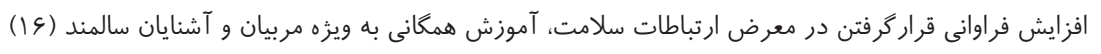

مفهوم سازى آنها براى مولفههاى سخت از متنون منتخب به تفصيل آمده است. مولفههاى نرم افزارى؛ مولفه هاى نرمافزارى به عوامل اصلى برنامهريزى علملياتى و تدوين راهبردهاى قابل اندازه گيرى مانند آموزش مادامالعمر

- ايجاد شرايط مطلوب در محيط شهرها و محيط زيست براى سالمندان؛ تقويت منابع انسانى. توسعه محيطهاى

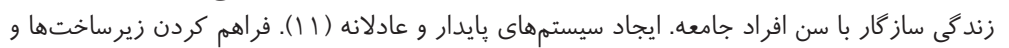

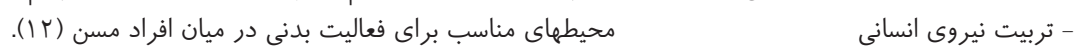

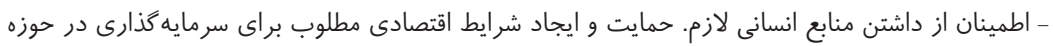

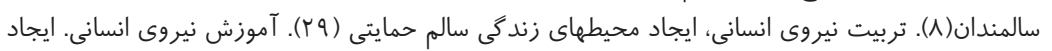

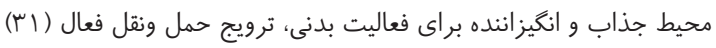

- دسترسى آزاد به خدمات اجتماعى و هشتيبانى مطلوب و داشتن يك زندگى فعال براى همه سالمندان.

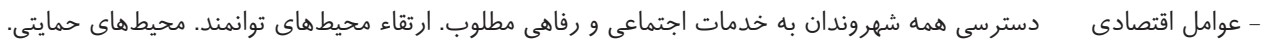

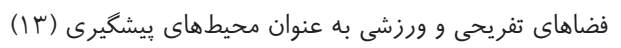

مولفه هاى اجتماعى و فوهنگي؛ مولفههاى اجتماعى و فرهنكى عوامل

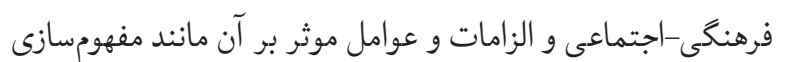
مجدد فعاليتبدنى و ادراك سالمندى، انخيزهها، ارزش هاو نكرشهاى اجتماعى-فرهنگى و مذهبى و فرهنگسازى و تغيير عادات مردم را تشريح مى كند؛ همجنين بر لزوم ايجاد كميّينها و رويدادهاى اجتماعى و داوطلبان براى ترويج و يشتيبانى از سالمندان و همجنين حمايت از مشاركت اجتماعى فراكير براى ايجاد تغيير تاكيد شده است. در جدول شماره F مضامين مستخرج از متون منتخب و دسته
يرداخته است. همجنين صلاحيت ارايه كنند كان جه در آموزش يا مربيگرى و ارايه مشاوره به سالمندان عامل تاثيرگذار است. در جدول شماره مضامين استخراج شده از متون منتخب و دسته بندى و مفهوم سازى آنها براى مولفههاى نرمافزارى به همراه مصاديقى از متنون منتخب به تفصيل آمده است. 
جدول سّ. مضامين استخراج شده از متون منتخب براى مفهوم سازى مولفههاى نرمافزارى

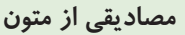

تمهاى فرعى

تم اصلى

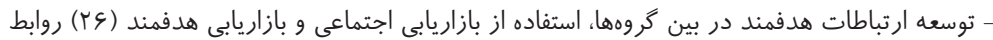

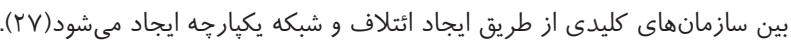

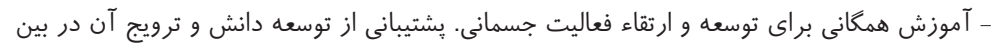

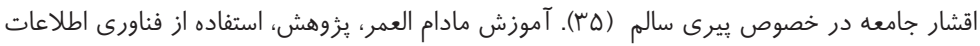

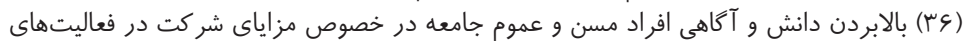

جنسمانى (rq).

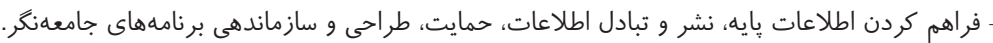

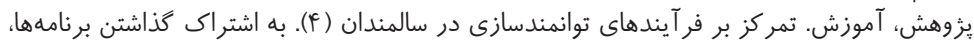

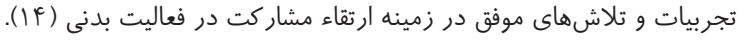

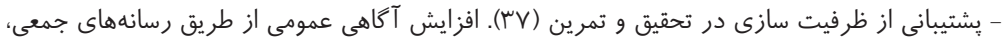

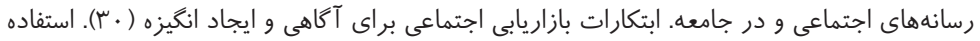

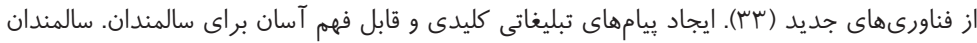

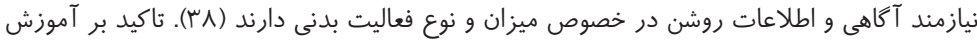

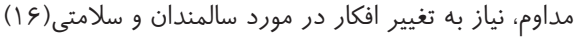

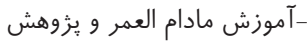

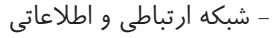

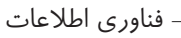

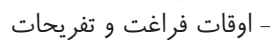
- ت خودمر اقبتى سالمندان

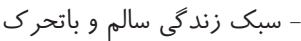

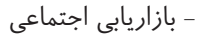

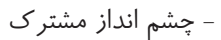
مولفههاى نرمافزارى

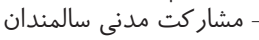
- صلاحيت ارايه كنندهها

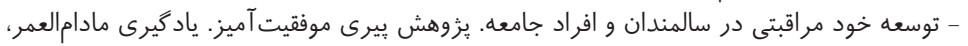

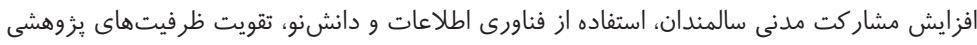

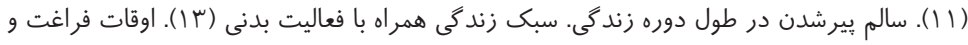

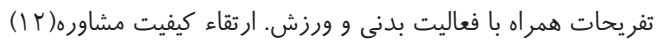

بندى و مفهومسازى آنها براى مولفهاى فرهنكى - اجتماعى به همراه تحريك كننده سالمندان هستند، همجنين در نظر داشتن رويكردهاى مرحله زندگى (برنامههاى متنوع و نوآورانه بر اساس سن و جنسيت)

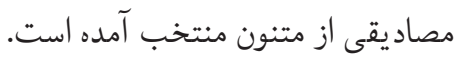
مولفههاى عملياتى و اجرايى؛ در نهايت مولفههاى عملياتى و و همجنين حمايت، تداوم و مقبوليت برنامهها برداخته است. در

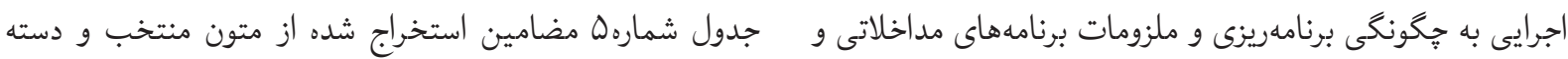

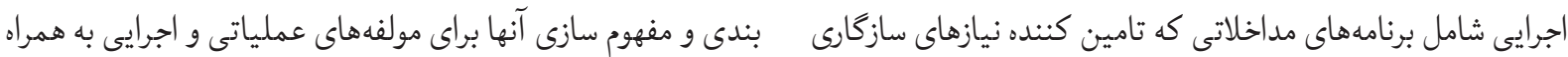
جدول عا. مضامين استخراج شده از متون منتخب براى مفهوم سازى مولفه هاى اجتماعى و فرهنىى

مصاديقى از متون

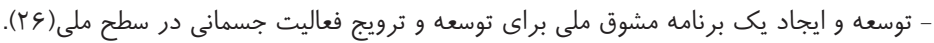

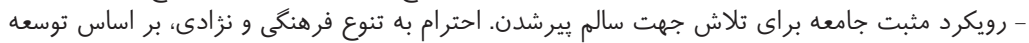

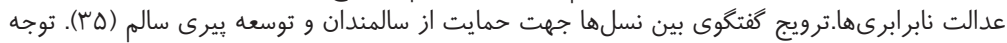

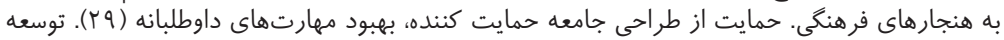

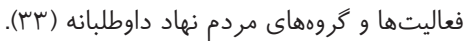

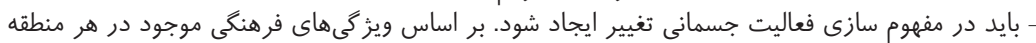

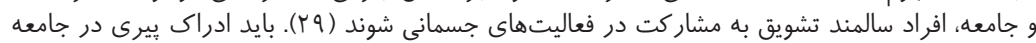

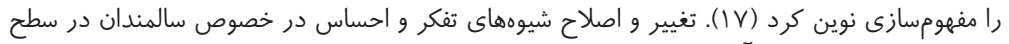

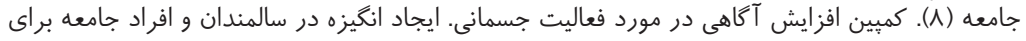

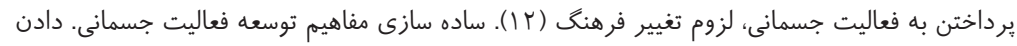

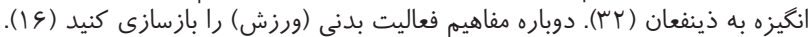

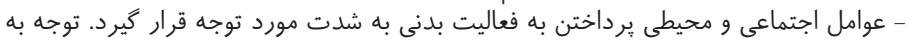

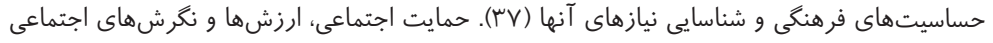

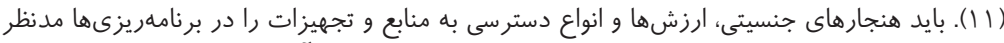

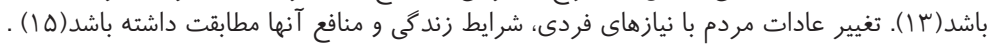

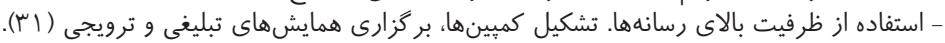

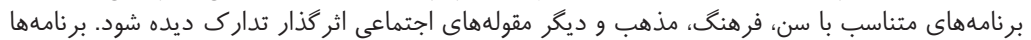

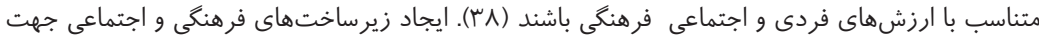

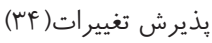

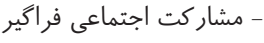

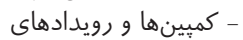

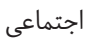

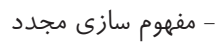

فعاليت جسمانى و ادراك مان

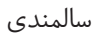

مولفه هاى فر هنگى - اجتماعى مولي

- انغيز هها، ارزشها و و

نكرش هاى اجتماعى -فرهنگى إنى و مذهبى اجتماعي - فرهنگ سازى و تغيير عادات مردم 


\begin{tabular}{|c|c|c|}
\hline مصاديقى از متون & تمهاى فرعى & تم اصلى \\
\hline 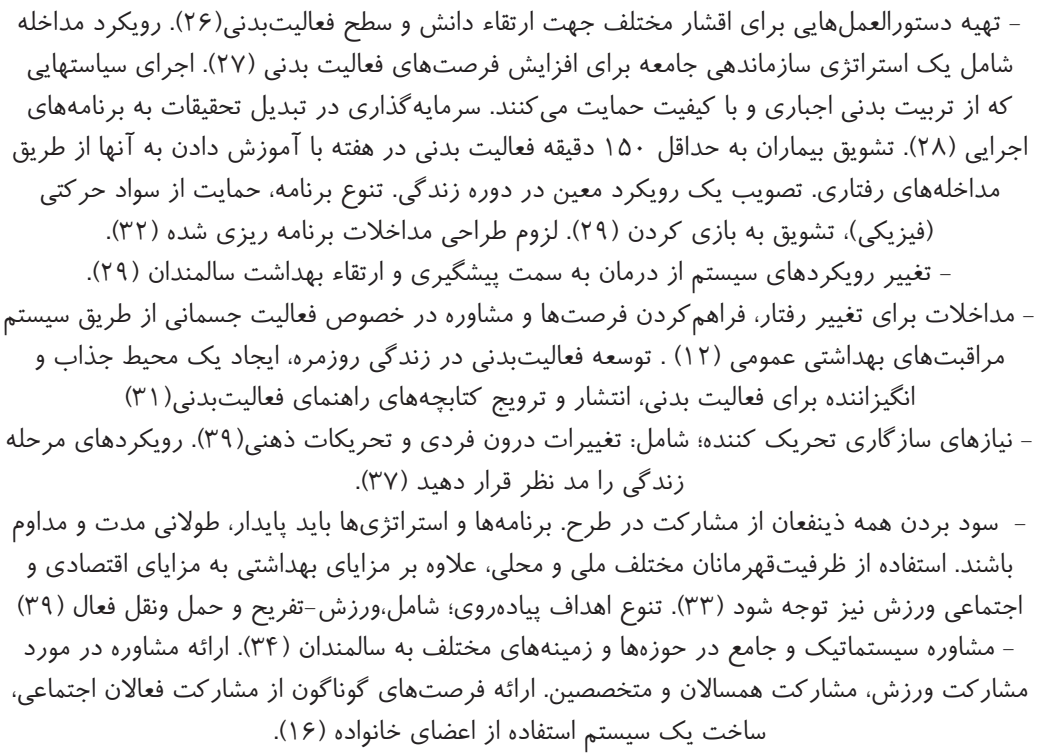 & 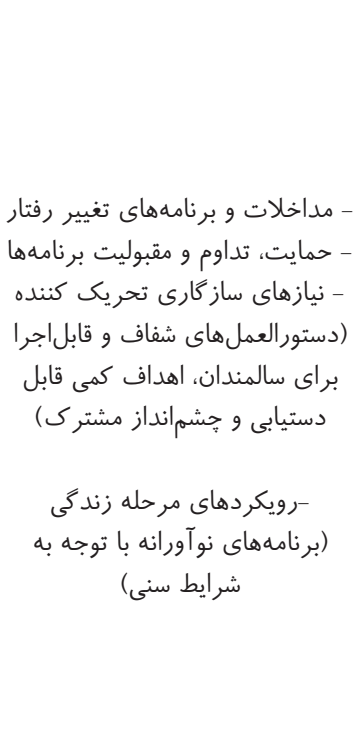 & $\begin{array}{c}\text { مولفهاى عملياتى اجر ايى } \\
\text { وايى }\end{array}$ \\
\hline
\end{tabular}

بشرى مورد تاكيد سازمانهاى بهداشتى بين المللى است ( أ, م). لذا

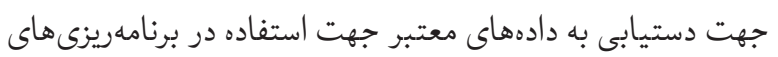

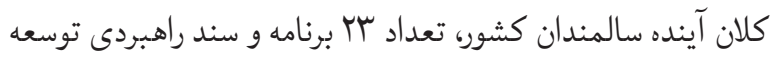
فعاليت جسمانى سالمندان از كشورهاى موفق مختلف و همرِنين

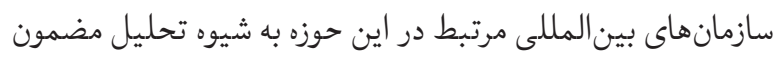

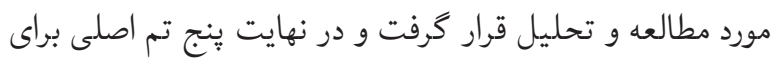

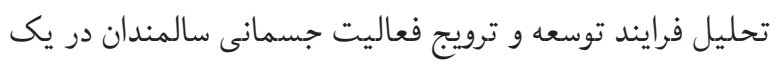

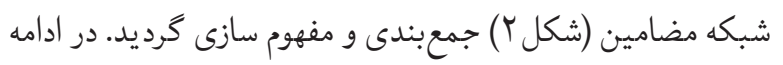
هر يك از تمهاى اصلى شبكه مضامين مذكور مورد بحث و نقد علمى قرار كرفته است. مو لفههاى ساختارى و بنيادى؛ زيربنايى ترين عامل موثر جهت

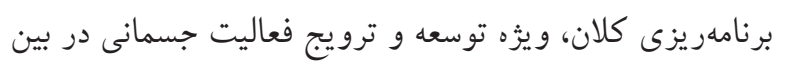

بررسى عميق و موشكافانه تجربيات موفق ديخران در برنامهريزى راهبردى به عنوان يك اصل از سوى صاحبنظران مورد تاكيد فراوان

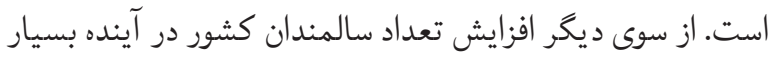

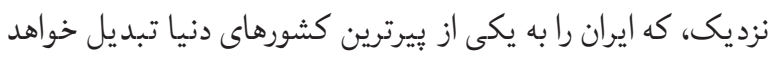

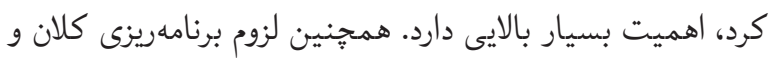

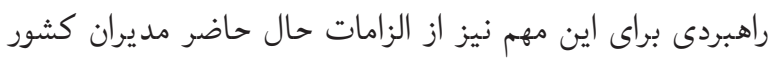

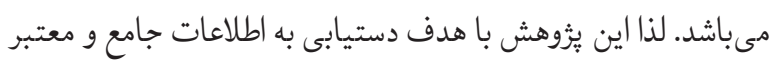
اقدام به بررسى موشكافانه، عميق و هدفمند اسناد و برنامههاى باى هدئ

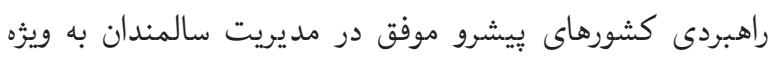
توسعه فعاليت جسمانى در اين قشر كرد. توسعه فعاليت جسمانى به عنوان موثرترين، عملياتى ترين و كم هزينه ترين شيوه در كنار ساير

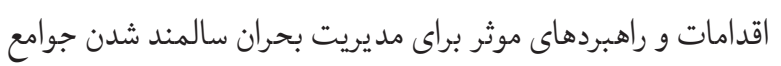




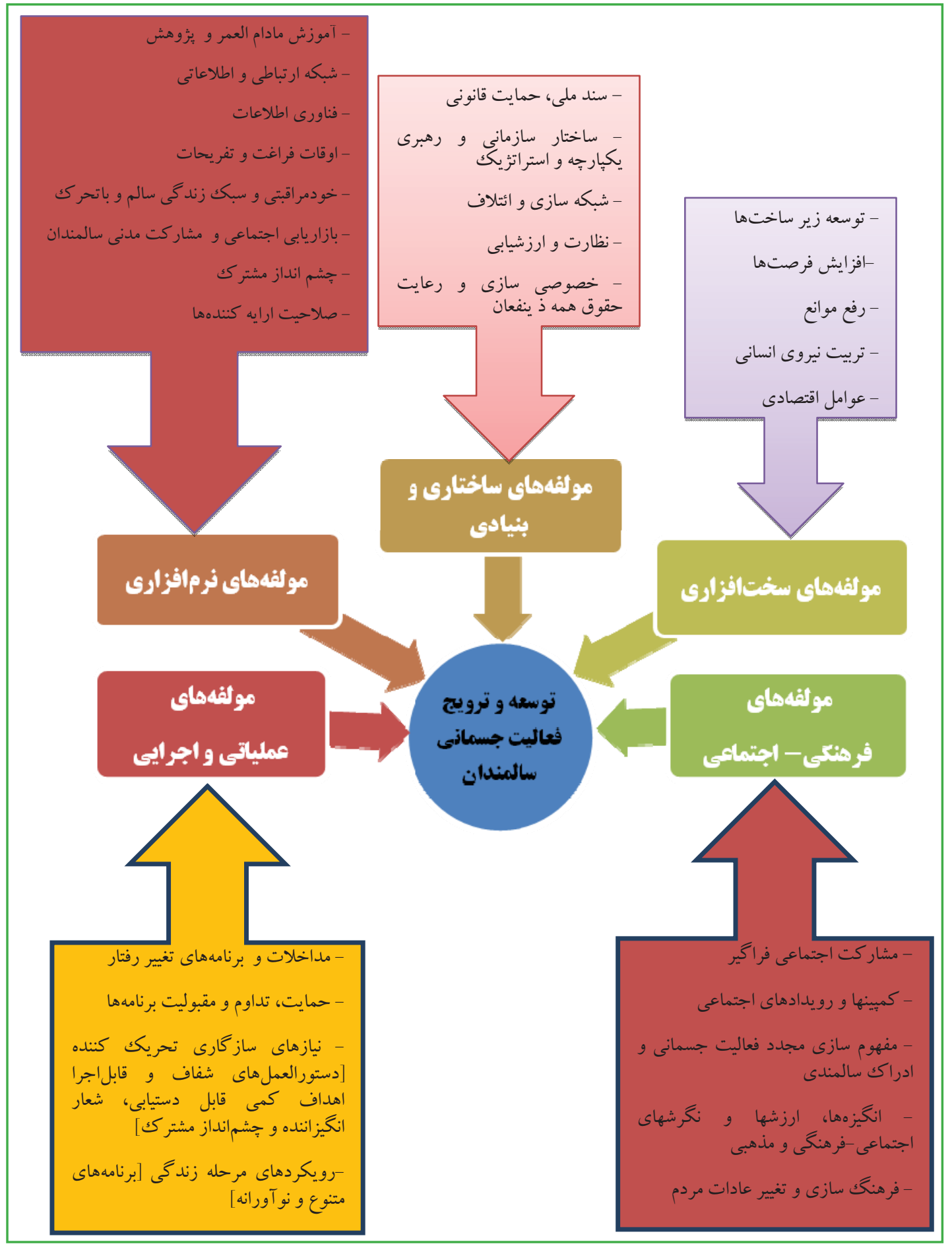

شكل r. شبكه مضامين عوامل موثر بر توسعه و ترويج فعاليت جسمانى سالمندان

سالمندان، مولفهاى ساختارى و بنيادى هستند. در واقع سنگ بناى قابل رصد كردن است. در برنامههاى راهبردى آمريكا براى توسعه

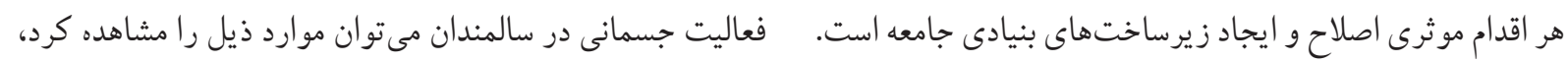

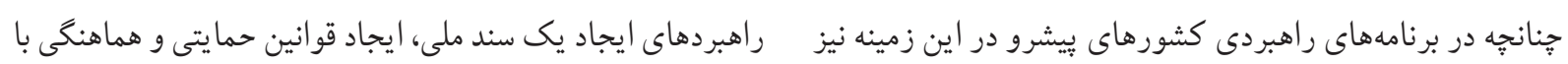


شرط يِيشبرد بسيارى از راهبردهاى ديكر در گرو تحقق مواردى

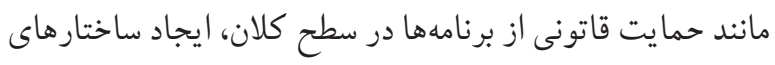

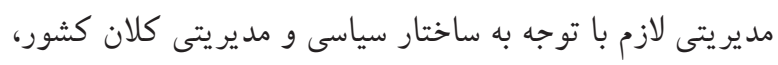
ورود و حضور جدى بخش خصوصى، رعايت حقوق همه ذينفعان

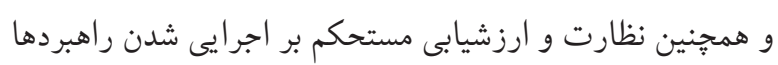

$$
\text { و برنامها است. }
$$

مولفههاى سخت افزارى؛ دومين عامل مهم و تعيين كننده

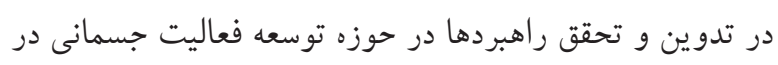
سالمندان توجه جدى به مولفههاى سخت افزارى است. بدون وجود ودرد

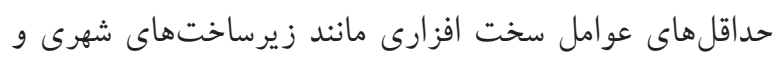
روستايى متناسب سالمندان جهت برداختن به فعاليت جسمانى سرانى

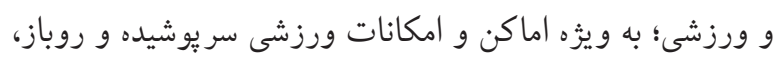

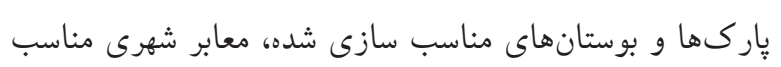

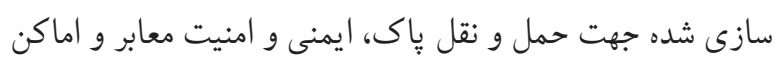

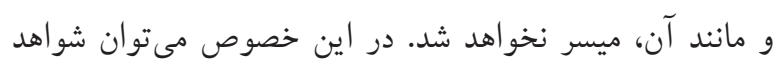
زيادى را در برنامههاى راهبردى كشورهاى ييشرو مشاهده كرد.

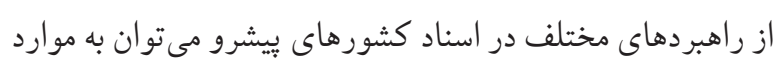
ذيل اشاره كرد؛ افزايش فرصتهاى فعاليت بدنى و كاهش موانع

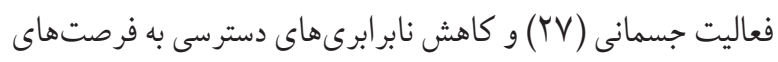

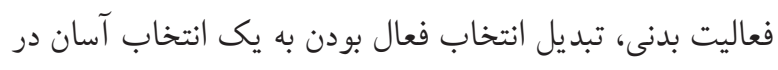

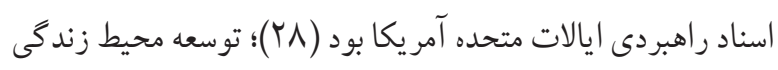

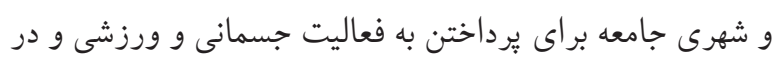
دسترس قراردادن بِرداختن به فعاليت جسمانى براى همه سالمندان

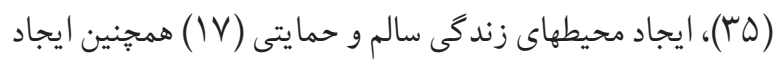

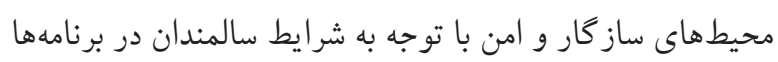

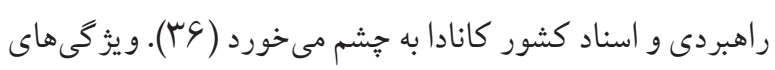
فيز يكى فضاهاى باز، كيفيت مسيرها و ميزان دسترسى به اين مكانها

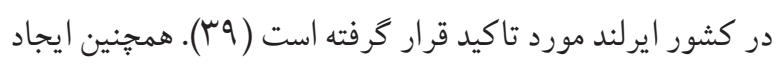

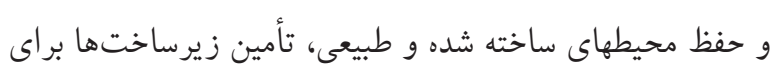

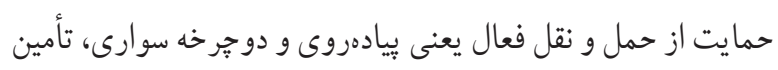

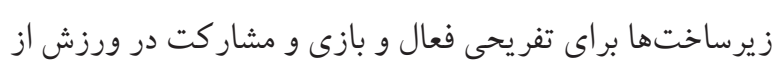

قانون گذاران (Yצ) و بكار گيرى اقدامات پِايدار با همكارى سطوح

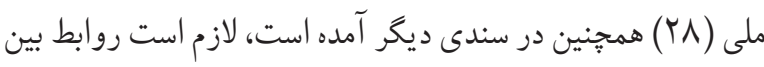

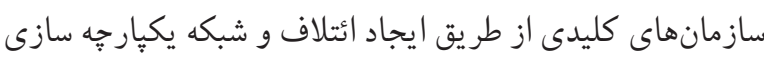

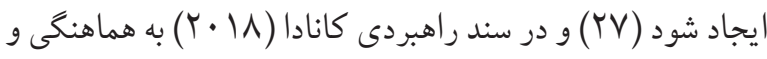

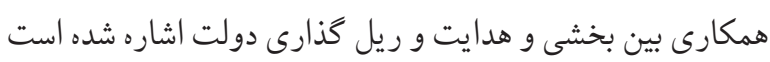

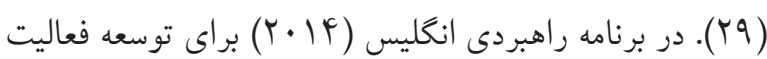
جسمانى در سطح جامعه نياز به مديريت و رهبرى قوى در سطوح

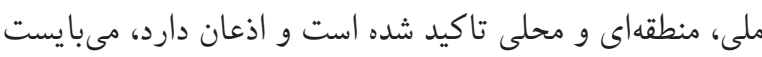

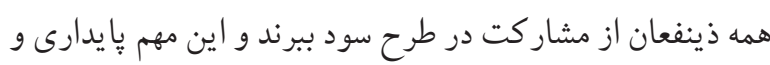

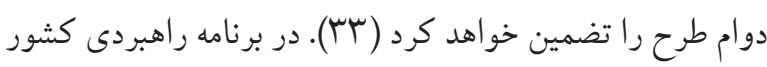

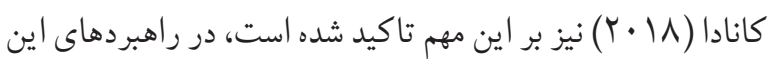

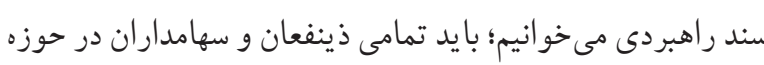
سلامت و ورزش سالمندان در برنامهريزىهاى آتى مشار كت داشته

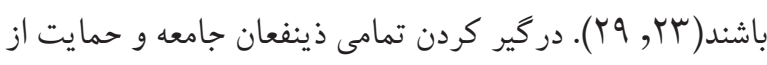
بخش خصوصى از راهبردهاى اصلى سند راهبردى آلمان (Y... (Y)

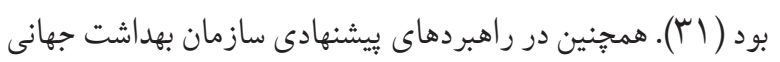

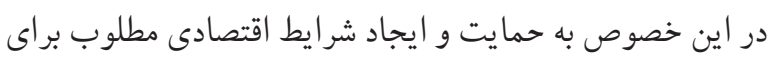
سرمايه گذارى در حوزه سالمندان تاكيد شده است (^) و اتحاديه ارو

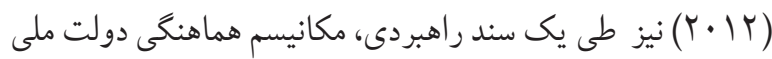

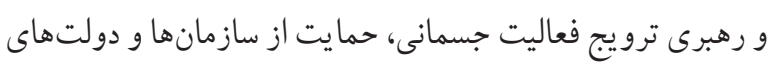

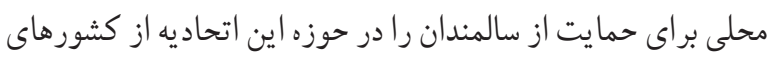

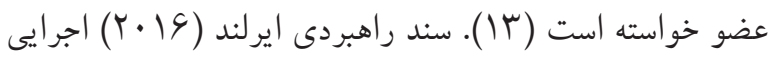

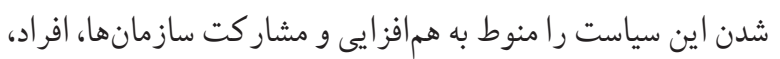

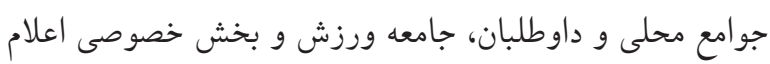
كرده است و تاكيد دارد كه هيج سازمانى به تنهايى نمى تو اند مردم كشور را فعالتر كند (ه) (1).

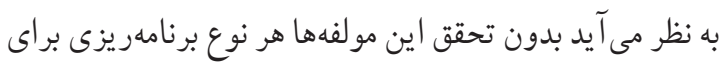

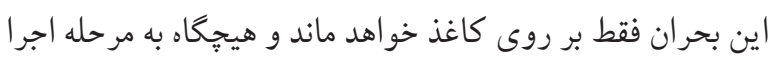

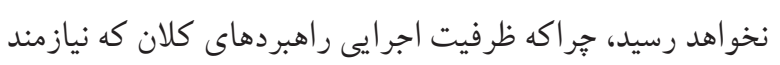
همكارى و هماهنكى سازمانهاى زيادى براى محقق كردن آنها است،

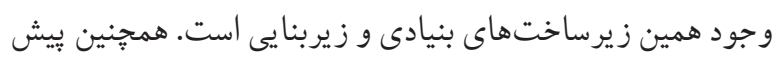


سالمندان به ويزه در خصوص مزاياى يرداختن به فعاليت جسمانى

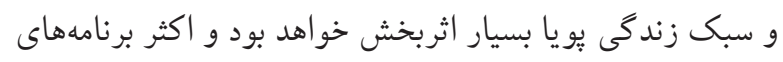

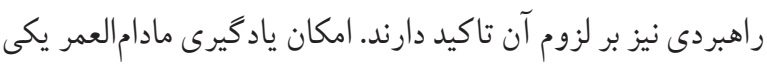
از سه اصل اساسى براى برنامه ريزى بيرامون جمعيت سالمندان كانادا

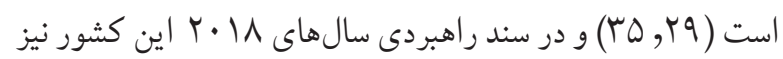
به آن تاكيد شده است (

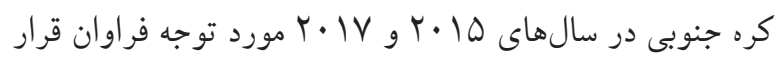

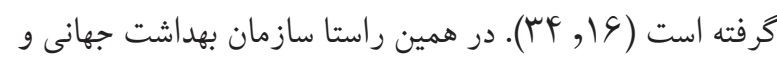

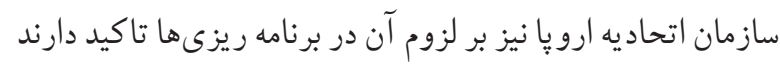

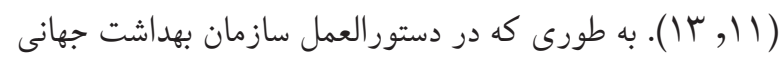

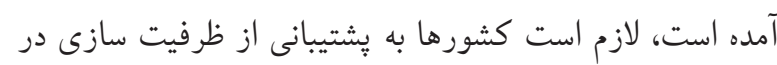

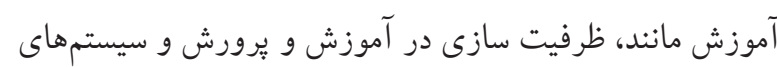
بهداشت عمومى در گير در زمينههاى تربيت بدنى، فعاليت بدنى و

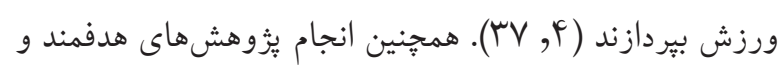

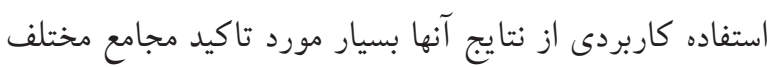

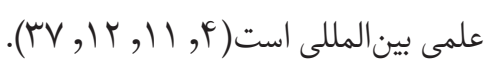
استفاده از شبكهاى ارتباطى در بين شهروندان و سالمندان

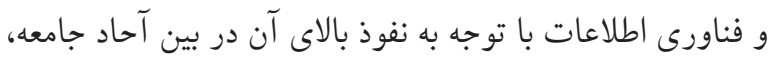

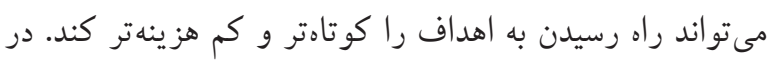

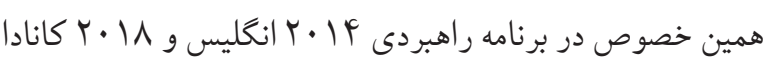

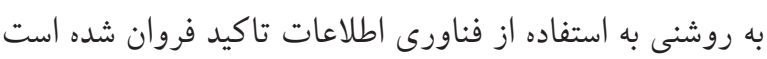
(Y, IV) عنوان يك راهبرد اساسى آمده است (Q إ) و در دستور العمل سازمان بهداشت جهانى بر استفاده از فناورى اطلاعات و دانش نو و همجنين

تقويت ظرفيتهاى ثزّوهشى كشورها توصيه شده است (11).

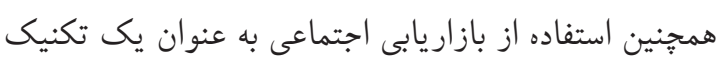

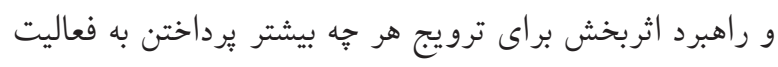

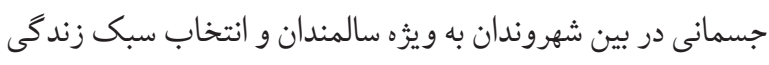

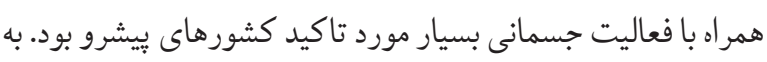

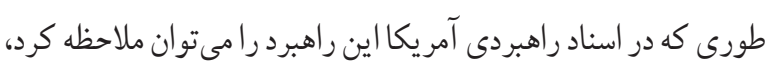

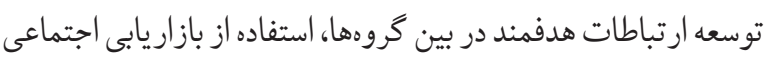

توصيههاى راهبردى سازمان بهداشت جهانى (T/ • (Y) در خصوص توسعه فعاليت جسمانى در سالمندان بود ( •־). در همين راستا اين سازمان ايجاد شرايط مطلوب در محيط شهرها و محيط زيست براى

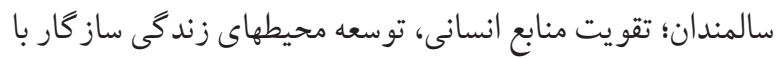

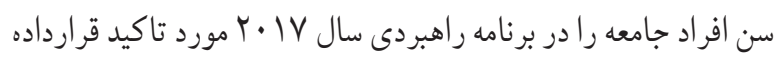

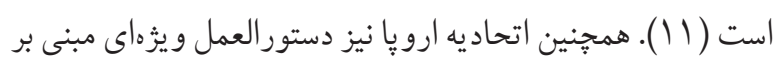
فراهم كردن زيرساختها و محيطهاى مناسب براى فعاليت بدنى

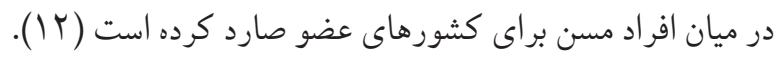

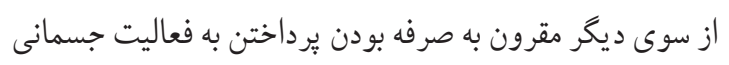

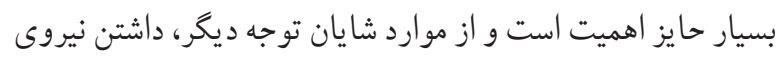

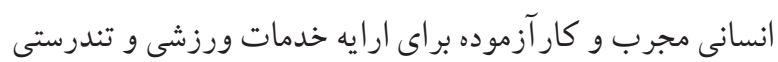

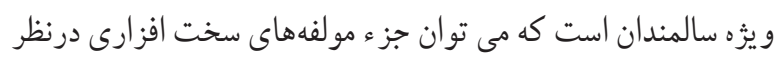

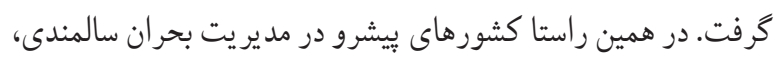

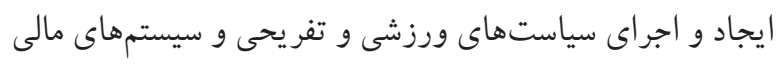

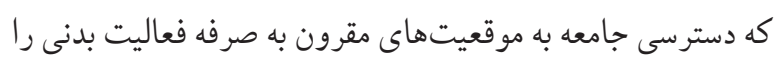

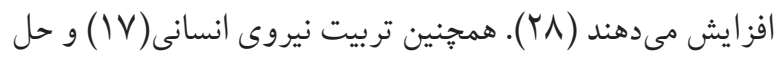
مشكلات اقتصادى (كاهش هز ينهاى برداختن به فعاليت جسمانى)

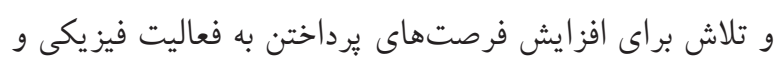

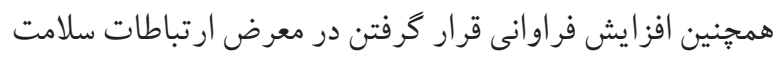

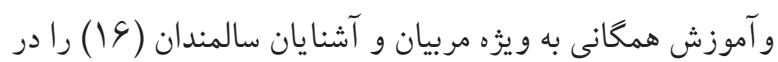
راهبردهاى خود مورد تاكيد قرار دادهاند.

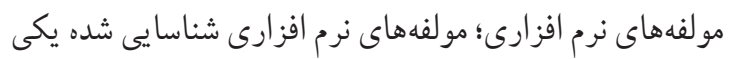

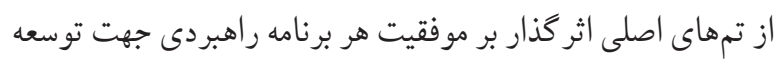

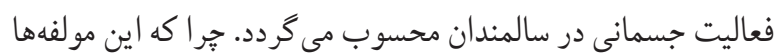
به عنوان بِ رابط و يبوند دهنده مولفه هاى بنيادى و مو لفههاى سخت

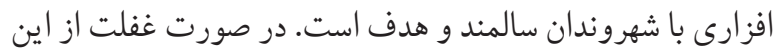

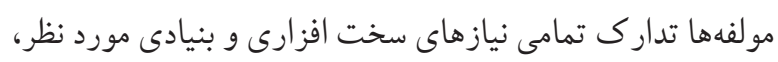
اثربخشى جندانى نخواهند داشت. زيرا در نهايت اين شهروندان و و سالمندان خو اهند بود كه مى بايست ترقيب و مجاب شوند از امكانات

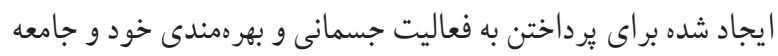

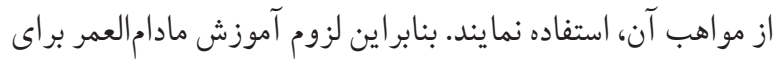


است، برنامهها مىبايست متناسب با سن، فرهنگ، مذهب و ديخر

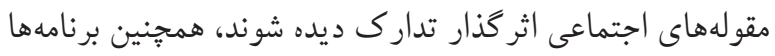
متناسب با ارزشهاى فردى و اجتماعى و فرهنكى باشند (rی) و

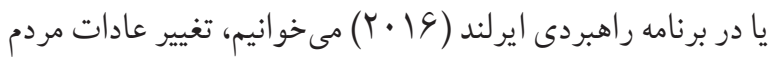

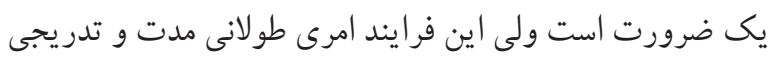

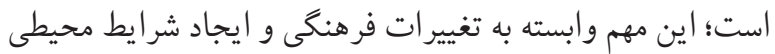

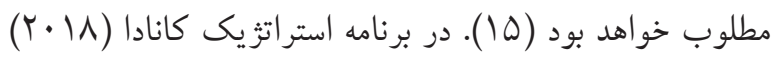

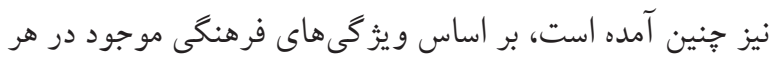

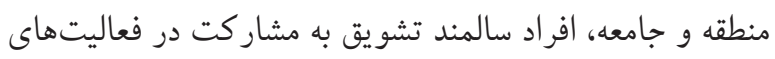

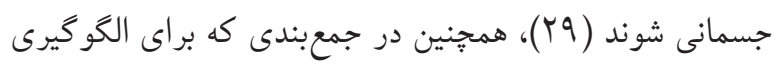

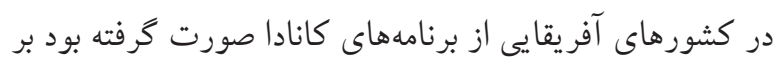

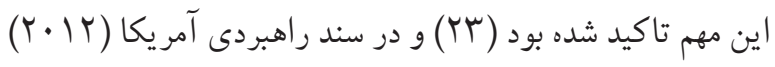
آمده است، اطمينان از اين كه راهبردها مطابق با حساسيتهاى

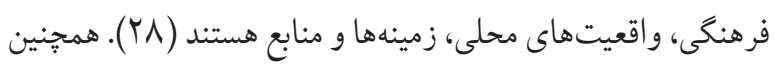
در راهبردهاى ييشنهادى سازمان بهداشت جهانى و اتحاديه ارو خا براى توسعه فعاليت جسمانى در سالمندان توجه ويثهاى به اين

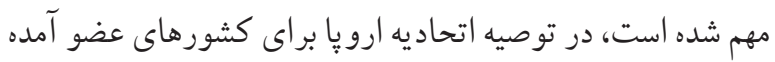

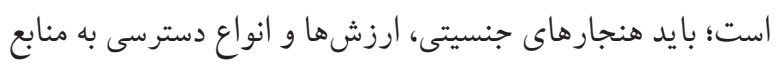

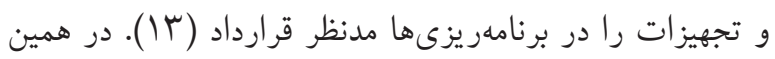

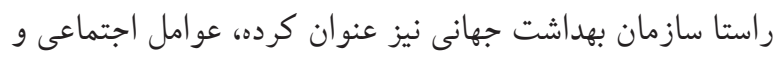
محيطى برداختن به فعاليت بدنى به شدت مورد توجه قرار كيرد و

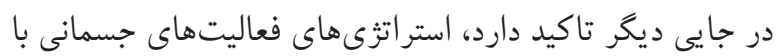

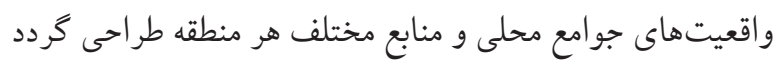

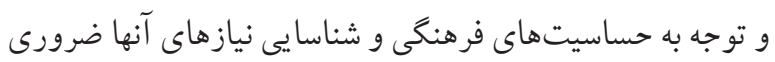
است (rV) و در سندى ديكر توجه به حمايت اجتماعى، ارزشها

و نكرشهاى اجتماعى تاكيد كرديده است (11).

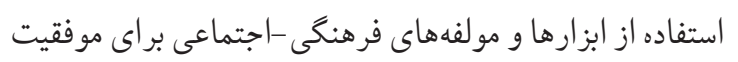
بيشتر و ويشبرد برنامهها و اهداف بسيار موثر خواهند بود. مانند

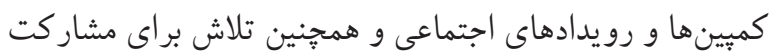

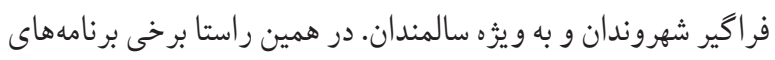

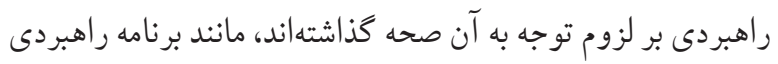

و بازاريابى هدفمند جهت توسعه فعاليت جسمانى در جامعه (Y9)، جهت كيرى بازاريابى، بيامهاى ترويجى و تبليغات به سمت تشويق فعاليت بدنى و دورى از عدم فعاليت بدنى و بىتحركى (Y^).

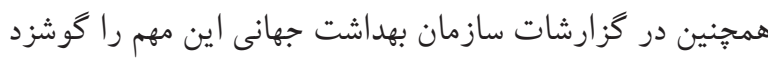
كرده است، استفاده از ابتكارات بازاريابى اجتماعى براى آكاهى درانى

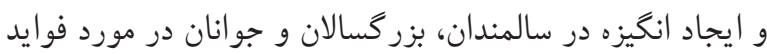
فعاليت بدنى و تسهيل رفتارهاى سالم ( • (ץ).

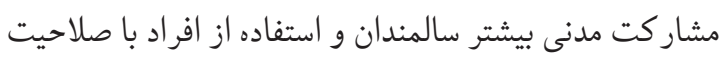
در ارايه برنامهها يك انتخاب و راهبرد هوشمندانه خواهد بود.

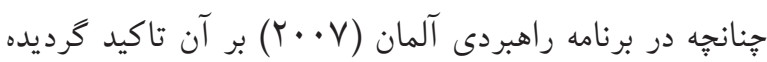

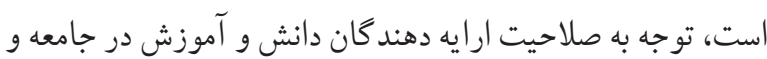

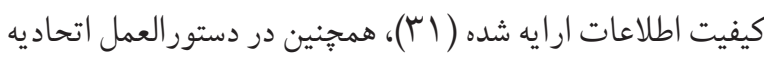

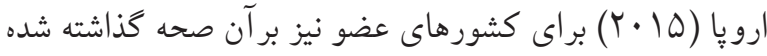
است، ارتقاء كيفيت مشاوره در مورد فعاليت بدنى توسط مشاوران بهداشت عمومى (Y I ). در گزارش سازمان بهداشت جهانى در سال

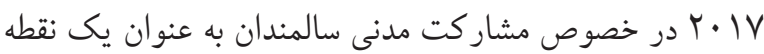

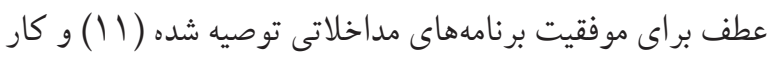

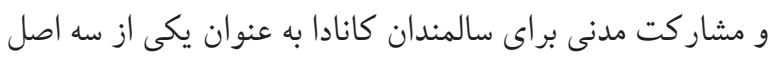

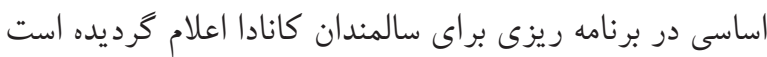

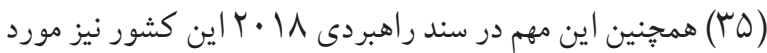
تاكيد قرار گرفته است (IV)

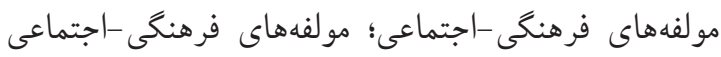
شناسايى شده در فرايند اين يثزوهش را به عنوان كاتاليزورى بسيار

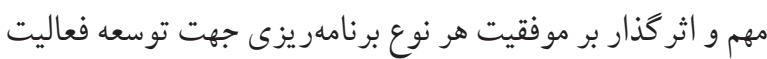

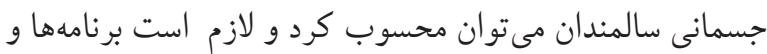
مداخلات طرحريزى شده، ملاحظات فرهنكى و اجتماعى هر منطقه

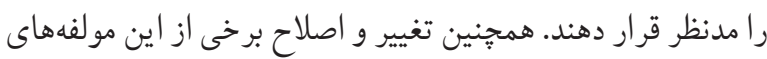
فرهنكى اخر جه ممكن است طولانى مدت باشند ولى اثربخشى آنها بر موفقيت يا عدم موفقيت رسيدن به اهداف، بسيار حايز اهميت

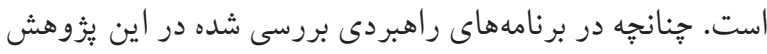
نيز بدان توجه ويزه شده است؛ در سند راهبردى انخلستان آمده 
است و لازم است حتما در راهبردها كنجانده شوند. اين مهم در

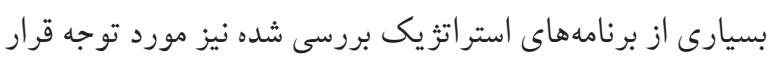

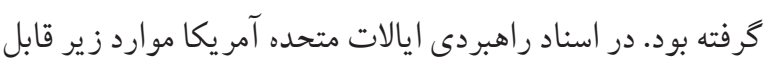
توجه هستند؛ تهيه دستو رالعمل هايى براى اقشار مختلف جهت ارتقاء

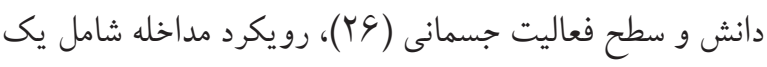

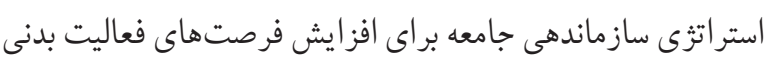

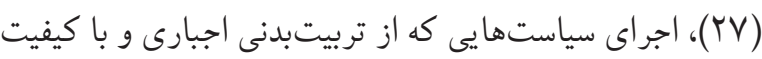

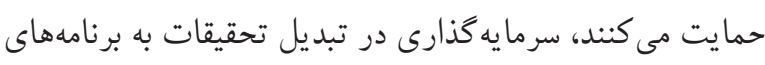

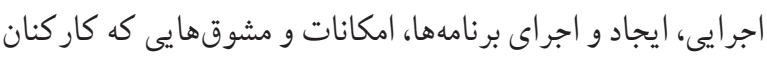

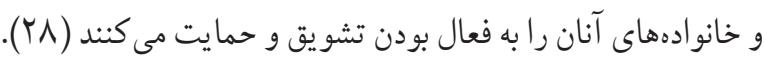
همجنين كشورهاى بيشرو ديكر نيز راهبردهايى را در دست اقدام

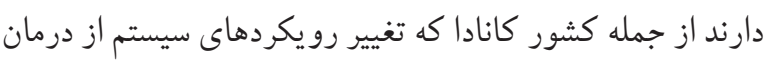
به سمت بيشكيرى و ارتقاء بهداشت سالمندان را مدنظر دارد (IV) يا آلمان كه لزوم طر احى مداخلات برنامه ريزى شده را به عنوان يك راهبرد اساسى در دستور كار قراردادهاست (Trا). در همين

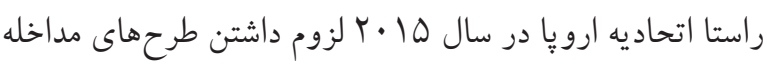

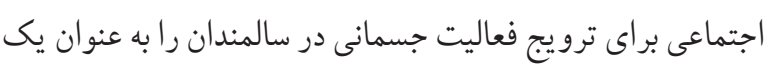

راهبرد براى كشورهاى عضو بيشنهاد داده است (T M (I).

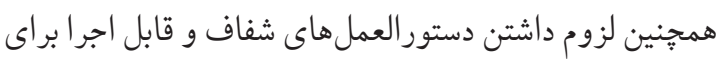

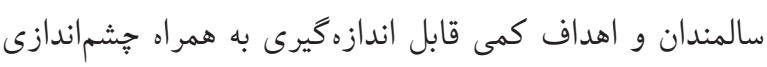

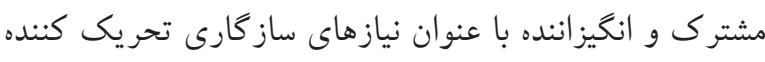
لازمه هر برنامه موفق در حوزه توسعه فعاليت جسمانى در سالمندان است. جنانجه در برنامههاى كشورهاى موفق به طور كسترده به آنها

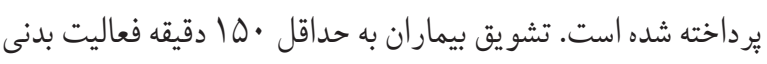

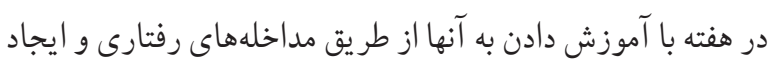

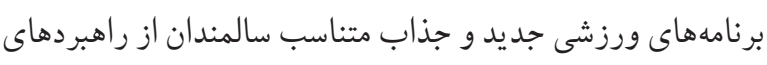

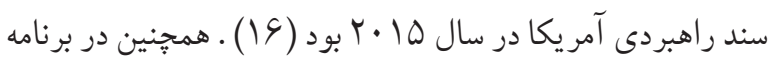

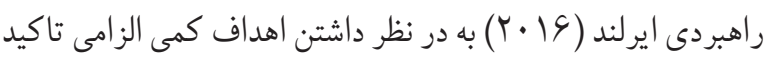

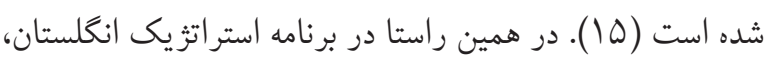

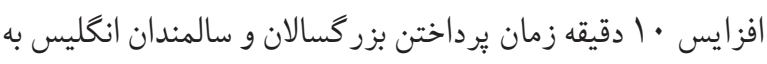
فعاليت جسمانى هدف كذارى شده است (Tr). همجنين در برنامه

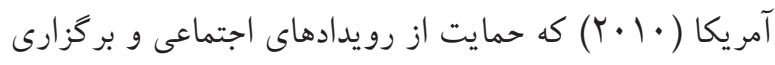

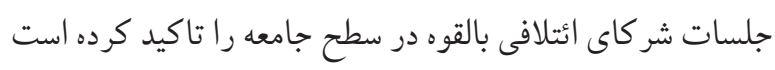

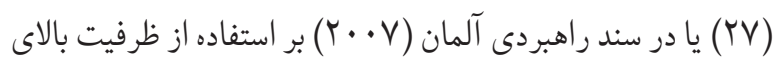

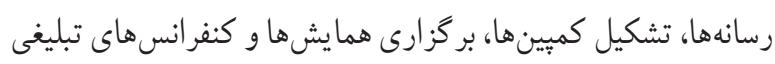

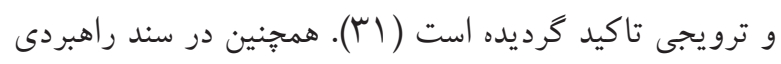

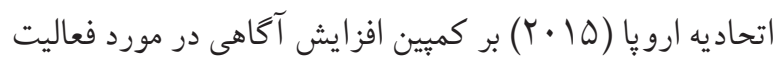

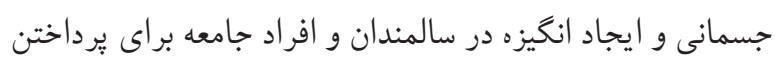

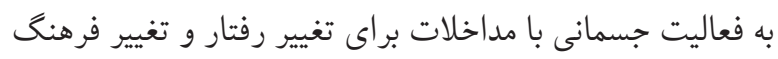

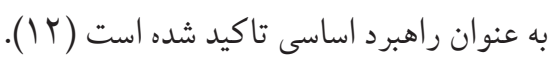
همجنين لزوم تغيير در ادراك مردم از يرداختن به فعاليت

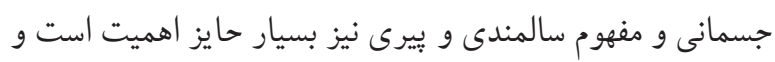

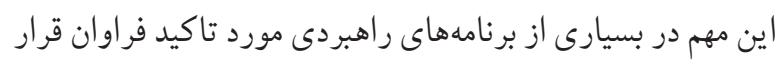

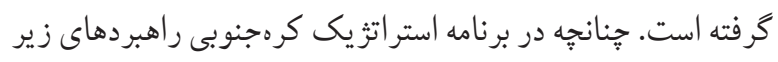

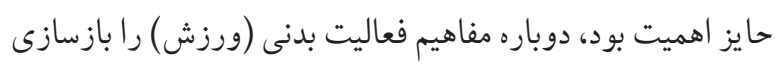

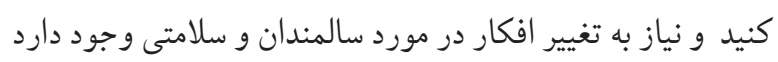
(19) يا در سند راهبردى كشورهاى مختلف يُشيشرو بر ترجمه مجدد

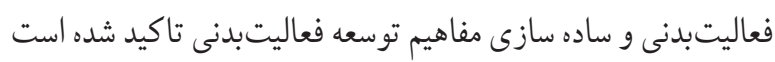

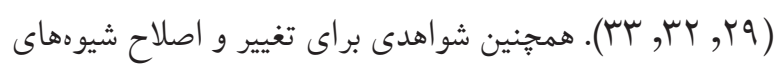
تفكر و احساس در خصوص سالمندان در سطح جامعه مورد تاكيد

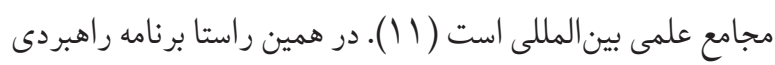

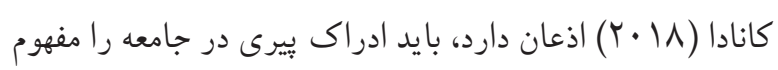

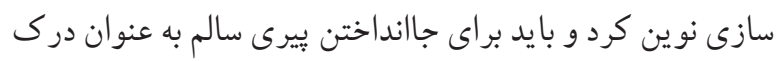

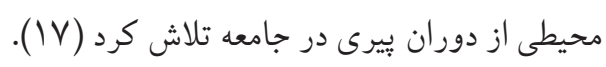

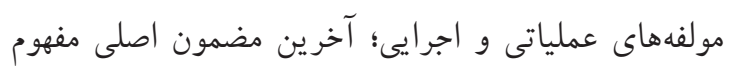
سازى شده در اين ئزوهش، مولفههاى عملياتى و اجرايى بودند.

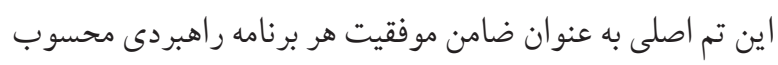

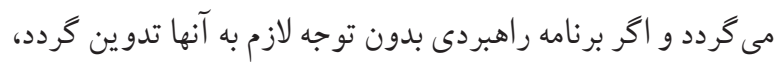

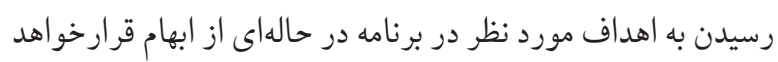

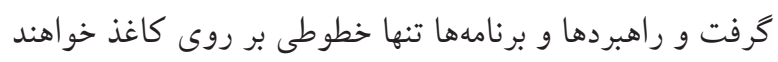

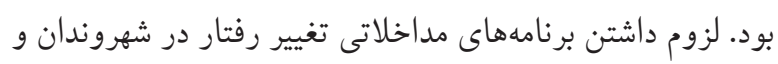

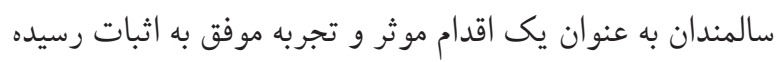


فعاليت جسمانى سالمندان در كشور كانادا يرداخته بودند با نتايج اين

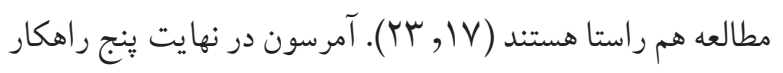
عمومى به عنوان توصيه بيشنهاد مى كند كه عبار تند از: تغيير در مفهوم

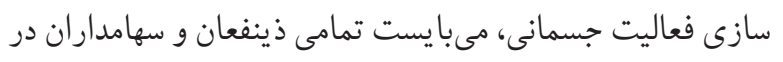

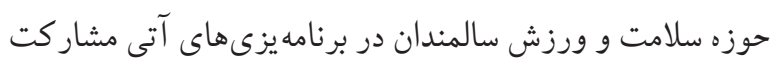

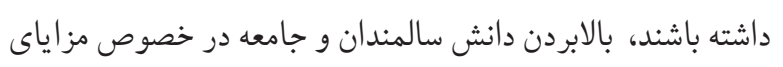

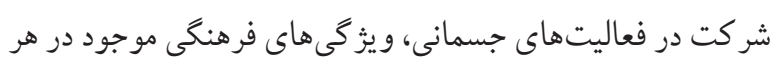
منطقه و جامعه مدنظر باشد، براى داشتن سالمندان سالم در آينده

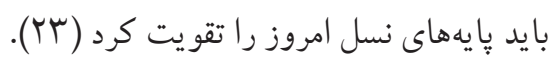

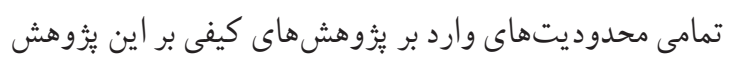
كه ماهيت كيفى دارد نيز وارد است. از جمله تعميم دادن نتايج

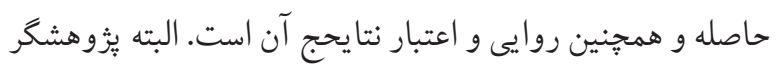
با بكار گيرى روشهاى علمى كه در قسمت روش كار تشريح شد،

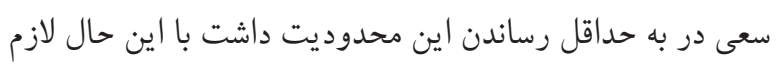

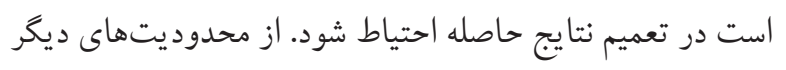
اين مطالعه، دسترسى يزووهشكر به منابع مطالعاتى بود، جر اكه زبان

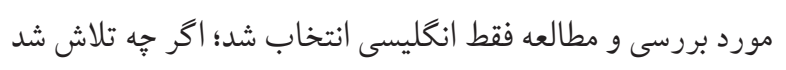

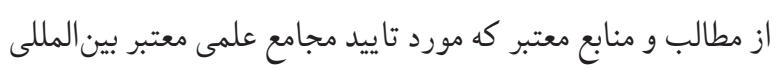

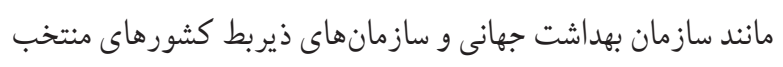
استفاده شود، ولى ممكن است منابع مفيد ديكرى نيز در برخى كشورهاى ديكر قابل رصد كردن باشد كه از حيطه بررسى و تحليل

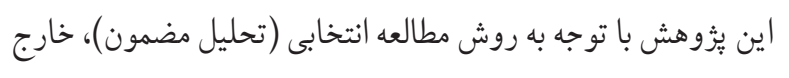

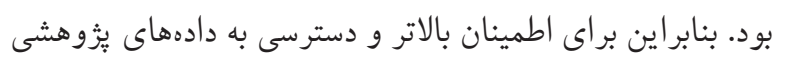

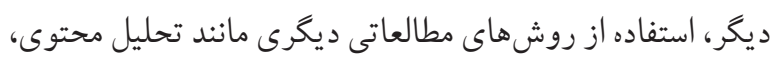

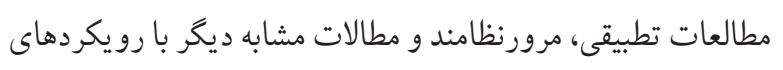

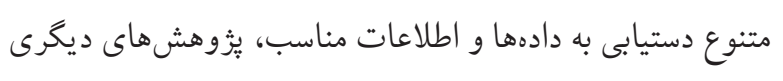
در دستور كار محققان اين حوزه قرار كيرد. نتيجه كُيرى و ارايه ويشنهادات يكى از حلقهاى مفقوده اصلى جهت برنامهريزى صحيح كلان و راهبردى جهت توسعه فعاليت جسمانى در سالمندان كه مورد تاكيد يُزوهشهاى داخلى در اين حوزه نيز بود و همجنين مورد توجه ويثره

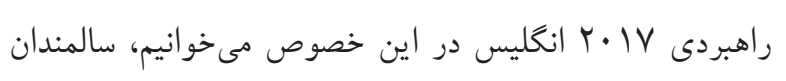

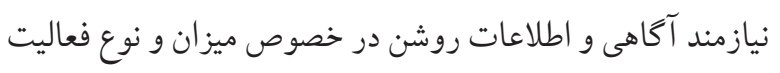

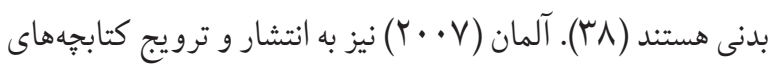

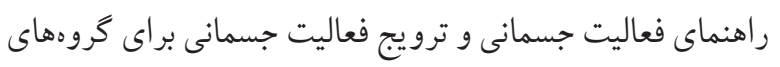
مختلف اجتماعى با رويكردى ساده و قابل فهم و كاربردى تاكيد

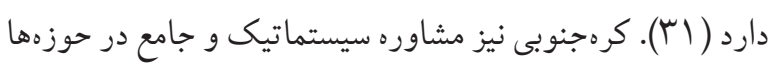

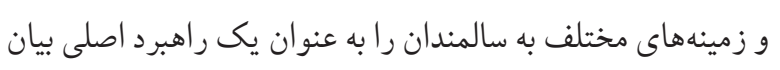

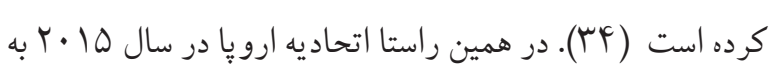
فراهم كردن فرصتها و مشاوره در خصوص فعاليت جسمانى در

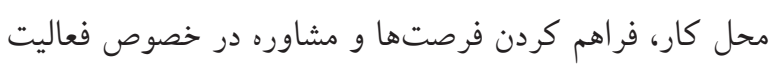

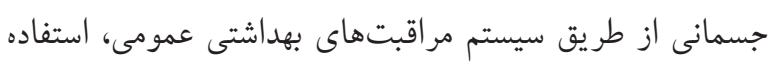

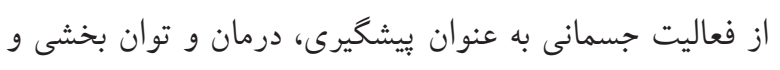

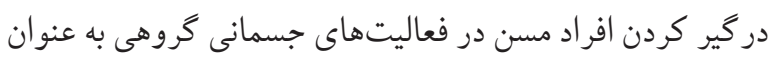
راهكارهاى عملياتى تاكيد كرده است (1 اI).

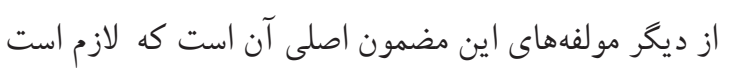

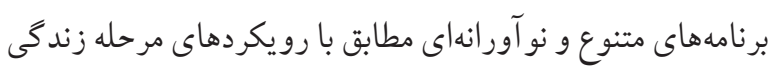
سالمندان تدارك گردد و با همكارى و مشار كت خود سالمندان به اجرا

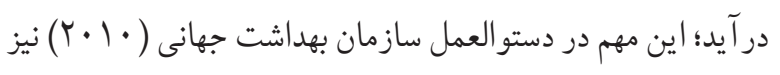

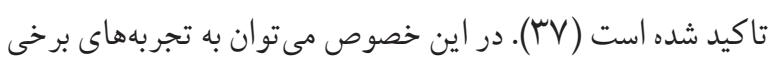
كشورهاى موفق اشاره كرد؛ مشاركت همسالان و متخصصين، اريائه فرصتهاى كوناكون از مشاركت فعالان اجتماعى، ييشنهاد راههاى

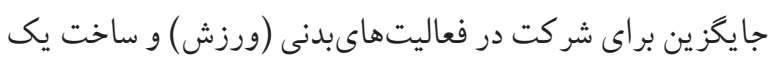

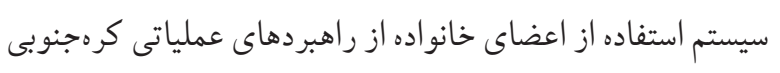

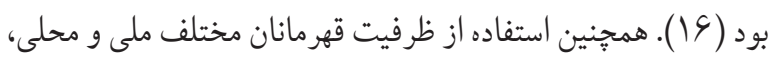

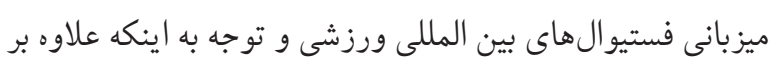

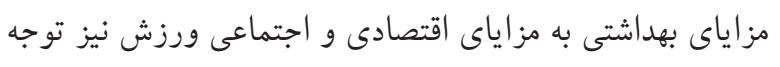
شود كمك كننده و انكيزاننده است در برنامه راهبردى انخلستان مورد تاكيد قرار كرفته است (بشا).

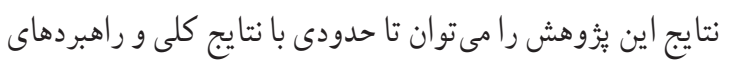

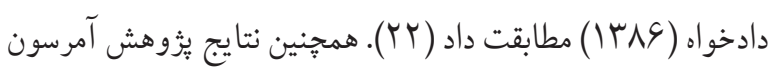

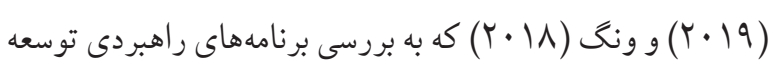


نيز از اهميت بالايى برخوردار است. جرا كه شرط لازم جهت دستيابى به اهداف ترسيم شده در نقشه راه، توجه به سطوح ميانى -نهادى و مقياس هاى خرد مديريت اجرايى براى هموارسازى اجراى راهبردها

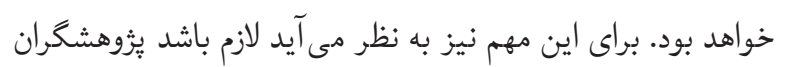
حوزه مطالعات سالمندان با يزوهش هاى مشابه اين مطالعه به بررسى نقادانه و موشكافانه برنامههاى عملياتى و مداخلاتى موفق اجرا شده در كشورهاى ييشرو به عنوان الخوى عملى موفق در اين حوزه با توجه به محدوديت هاى فرهنكى - اجتماعى و قانونى ايران برداخته و نتايج آنها را بومى سازى نمايند. تشكر قددانى اين مقاله قسمتى از رساله دكترى نويسنده اول با عنوان ((نقشه راه توسعه و ترويج فعاليت جسمانى در سالمندان كشور)) با كد يرويزال تصويب شده در دانشكده تربيت بدنى و علوم ورزشى دانشگاه خوارزمى تهران به شماره (كيفى) و اهداف درنظر گرفته شده براى آن (تحليل مضمون) كه فاقد نمونههاى انسانى يا حيوانى بود، نيازى به اخذ كد اخلاق نداشت. همجنين بدينوسيله از راهنمايىهاو تلاشهاى ارزنده اساتيد راهنما

$$
\text { و مشاور كمال تشكر و قدردانى را دارد. }
$$

\section{References}

1.MirzaieM,DarabiS.PopulationAginginIranandRisingHealthCare Costs. Salmand: Iranian Journal of Ageing. 2017;12(2):156-69. https://doi.org/10.21859/sija-1202156

2. Taipale V. The Global AgeWatch Index, GAWI 2013. Gerontechnology. 2014;13(1):16-20. https://doi.org/10.4017/gt.2014.13.1.010.00

2. Rahaei Z, Mehrjoyan N, Barzegr F, Anbari-Nogyni Z. Is Higher Health Literacy Associated with Better Self-Care in the Elderly? Journal of Health Literacy. 2020;5(3):26-35. https://doi.org/10.22038/jhl.2020.53305.1135

4. Tehrani H. Mental health stigma related to novel coronavirus disease (COVID-19) in older adults. Geriatrics \& Gerontology International. 2020;20(8):796-7. h tt p s : / / d o i . org / $10.1111 /$ g g i . 13985 PMid:32639082 PMCid:PMC7361788

5. Jhala. N CA. Active aging. International Journal of Humanities and Social Science Intervention. 2013; 2(1):1-4.

6. Foster L, Walker A. Active and successful aging: A European policy perspective. The gerontologist. 2015;55(1):83-90..
سازمانهاى بهداشتى بين المللى قراردارد، استفاده از تجارب موفق كشورهاى بيشرو به عنوان الخوى مناسب و عينى است. در اين جستار سعى شد با بررسى موشكافانه و دقيق اسناد و برنامههاى راهبردى كشورهاى موفق در اين حوزه نكات ارزشمند و مفيدى كه ممكن است در برنامهريزىهاى آتى كشور براى مديريت بحران بيشرور مفيد باشد، استخراج، مفهوم سازى و گزارش كردد. انتظار مى رود تصميم گيران، تصميمسازان، دستاندركاران و مديران ارشد بخش سلامت و ورزش كشور با استفاده از مولفها و مضمونهاى فرعى و اصلى استخراج و مفهوم سازى شده در اين مطالعه برنامههاى كلان، راهبردى و عملياتى قابل اجرا و مفيدى را براى مواجه و مقابله با سالمند شدن جمعيت كشور و داشتن فرايند بيرى موفقيت آميز شهروندان، تدارك ديده و اجرا نمايند. همجٍنين لازم است براى مواجه و مديريت بحران بسيار جدى در يِيشرو كه هيج نيرويى قادر به متوقف كردن آن نخواهد بود، با عنايت به نتايج اين مطالعه و انجام يثزوهشهاى تكميلى مانند تحليل نظرات ذينفعان و صاحبنظران حوزه توسعه فعاليت جسمانى و وززش همخانى، شناخت نقاط قوت و فرصتهاى موجود در كشور، اقدام به برنامهريزى راهبردى و تدوين نقشه راه توسعه و ترويج فعاليت جسمانى در بين سالمندان كرد. البته تدوين و ارائه برنامههاى عملياتى جهت دستيابى به راهبردها

https://doi.org/10.1093/geront/gnu 028 PMid:24846882 PMCid:PMC4986585

7. Eime .R HJ, Payne.W, Brown. W. Club sport: Contributing to health-related quality of life. Journal of Science and Medicine in Sport. 2010;12:221-32. https://doi.org/10.1016/j.jsams.2009.10.184

8. Organization WHO. 10 Priorities for a Decade of Action on Healthy Ageing. WHO/FWC/ALC/17.1 C WHO 2017. Some rights reserved. In: licence TwiautCB-N-SI, editor. 2017.

9. Shin SDS. Effective tempo of the step test for dynamic balance ability in the elderly. Physiol Anthropol. 2007;26(6):563-70. https://doi.org/10.2114/jpa2.26.563 PMid:18174663

10. Alonso SL. Analysis of physical activity as an integral element of active aging. International Journal of Development Research. 2019;9(1):25330-6.

11. Organization WH. Global strategy and action plan on ageing and health ISBN 978-92-4-151350-0. https:// creativecommons.org/licenses/by-nc-sa/3.0/igo. 2017. 
12. Europe WROf. Physical Activity strategy for the WHO European Region 2016-2025. In: Vilnius L, 14-17 September 2015. http://www.euro.who.int/en/who-weare/governance., editor. 2015.

13. Europe WHOROf. Strategy and action plan for healthy ageing in Europe, 2012-2020, http://www.euro.who.int/ en/who-we-are/governance. 2012. 1-28.

14. Tuso P. Strategies to Increase Physical Activity. Perm Journal. 2015;19(4): 84-8 ht tps: / / doi.org / 10.7812 / T P P / $14-242$ PMid:26517440 PMCid:PMC4626000

15. Department of Transport TaSDoH. Get Ireland Active! The National Physical Activity Plan for Ireland. 2016: 1-46.

16. Koo K-M, Park, Ch-H., Kim, Ch-J.,. Development of strategies for changing in physical activity behaviors on older adults with disabilities. Journal of Exercise Rehabilitation. 2017;13(6):676-83. https://doi.org/10.12965/jer.1735144.572 PMid:29326900 PMCid:PMC5747203

17. Wong RY. A New Strategic Approach to Successful Aging and Healthy Aging. Geriatrics. 2018;3(86):1-4. https://doi.org/10.3390/geriatrics 3040086 PMid:31011121 PMCid:PMC6371117

18. Jorkesh S, Nazari, R., Taheri, M. The Elderly Sport Model: Grounded Theory Approach. Sport Management Studies. 2019;11(55):35-58.

19. Jorkesh S NRJ. Future study of Iran's elderly sports using cross-impact matrix. Shahid Sadoughi Uni Med Sci. 2019;26(12): 1095-109. https://doi.org/10.18502/ssu.v26i12.666

20. javadipour M, rahbari, S. Identification of the Components Effective on Policy-Making in Sport for All in Iran. Science and Technology Policy Letters. 2017;7(3): 75-84.

21. Javadi Pour M, Rouhi Dehkordi, M., Rahbari, S., \& Taefi, H. Pathology the Process of Policy-Making in Sport for All in Iran and Presentation the Model. Sport Management Studies. 2019;10(52):17-42.

22. Dadkhah A. Review of Aged Rendered Services in USA and Japan and Guidelines for Iran Aging Strategic Plan. Iranian Journal of Ageing Salmand. 2007;2(1):166-76.

23. Amosun. S L DB, Patricia. K. What can Sub-Saharan Africa learn from Canada's investment in active healthy ageing? A narrative view. Malawi Medical Journal 2019;31(1):95-8. http s: / / o i.org/10.4314/m m j.v31i 1.16 PMid:31143404 PMCid:PMC6526340

24. Khanifar. H MN. Fundamentals Qualitative research methods new and practical approach. Tehran. Iran: negahedanesh; 2019.

25. H K. A Method for Calculating Coding Reliability in Qualitative Research Interviews. 2009;15(58):161-74.

26. Sheppard L, Senior, J., Park, C. H., Mockenhaupt, R., Bazzarre, T., \& Chodzko-Zajko, W. Strategic priorities for increasing physical activity among adults age 50 and older: The national blueprint consensus conference summary report. Journal of Sports Science and Medicine. 2003;2(4):169-74. https://doi .org/10.1123/japa.11.3.286 PMid:24688279

27. Cheadle. A; Egger. R LJ, Walwick. J, Schwartz Sh. CommunityOrganizing Approach to Promoting Physical Activity in Older Adults: The Southeast Senior Physical Activity Network. Health Promotion Practice. 2010;11(2):197-204. https://doi.org/10.1177/1524839908318167 PMid:18490486

28. Kohl HC, CL. Lambert, EV. Inoue, S. Alkandari, J R, Leetongin, G, Kahlmeier, S. The Pandemic of Physical Inactivity: Global Action for Public Health. The Lancet. 2012; 3800: 294-305. https://doi.org/10.1016/S0140-6736(12)60898-8

29. actifs UVcpflaperlsaCS. A Common Vision for Increasing Physical Activity and Reducing Sedentary Living in Canada: Let's Get Moving. . In: Federal patg, editor. 2018. p. 51 pages. www.canada.ca.

30. Organization WH. Global action plan for the prevention and control of noncommunicable diseases 2013-2020. World Health Organization2013.

31. Germany FMoH. German national initiative to promote healthy diets and physical activity. . 2007.

32. Rütten AA-O, K. Messing, S. Weege, M. Pfeifer, K. Geidl, W and Hartung V. How can the impact of national recommendations for physical activity be increased? Experiences from Germany. Health Research Policy and Systems. 2018;16(121):1-10. https://doi.org/10.1186/s12961-018-0396-8 PMid:30547824 PMCid:PMC6295091

33. landan HGMo. Moving More, Living More; The Physical Activity Olympic and Paralympic Legacy for the Nation. The National Archives,Kew, LondonTW9 4DU https:// assetspublishingservicegovuk/government/uploads/ system/uploads/attachment_data/file/279657/moving_ living_more_inspired_2012pdf. 2014.

34. Government Sm. A Comprehensive Plan for 50+ Assistance. $50+$ Renaissance for the Future of the Middle-aged and Elderly. http://english.kompass.kr/policy-information/ welfare-health-security/comprehensive-plan-50assistance/50-renaissance-future-middle-aged-elderly/. 2015.

35. Group THAaWW. Healthy Aging in Canada: A New Vision, a Vital Investment. A Discussion Brief Prepared for the Federal, Provincial and Territorial Committee of Officials. Health Agency of Canada. https://www.health.gov.bc.ca/ library/publications. 2006.

36. Jeffery B, Muhajarine, N., Johnson, S., Mclntosh, T., Hamilton, C. \& Novik, N. An Overview of Healthy Aging Strategies in Rural and Urban Canada. In: Unit SPHaER, editor. University of Regina and University of 
Saskatchewan2018.

37. Activity GACfP. International Society for Physical Activity and Health. In: Action TTCfPAAGCt, editor. 2010.

38. Foundation $\mathrm{BH}$. Active for later life; Promoting physical activity with older people. In: http://www.laterlifetraining. co.uk/wp-content/uploads/2017/08/BHFAFLLPDFSec1 GftBhf, editor. 2017.
39. Cassarino.M B-WE, Setti. A. Cognitive and Sensory Dimensions of Older People's Preferences of Outdoor Spaces for Walking: A Survey Study in Ireland. International Journal of Environmental Research and Public Health. 2019;16(1340):1-12. https://doi.org/10.3390/ijerph16081340 PMid:31013969 PMCid:PMC6518375 